\title{
No Sticks in My Bundle: Rethinking the Indian Land Tenure Problem
}

\author{
Jessica A. Shoemaker ${ }^{*}$ \\ "[T]hey were convinced that private property by itself would \\ transform the Indians."
}

\section{INTRODUCTION}

American Indian land tenure has long been the target of federal policies seeking to change, through property law reforms, indigenous peoples' relationships to each other, to the land and natural environment, and to surrounding non-Indian influences. Many of these top-down land reforms have had negative effects for Indian landowners and Indian communities. Two of the most direct and well-documented consequences are a pervasive pattern of fractionation or co-ownership within individually owned Indian lands and a persistent, restrictive federal trust status through which the federal government, as trustee, exercises significant land management oversight and control on Indian lands.

This article focuses on another change in individual Indians' property rights that has not previously been identified or studied indepth: the gradual elimination of any presumptive right of individual Indian owners to use and possess land they jointly own with one or more co-owners. This modern Indian property rule means that Indian coowners of land enjoy no default right to use and possess their own property. This no-use and no-possession rule for Indian co-owners is

\footnotetext{
* Assistant Professor of Law, University of Nebraska College of Law. I owe particular thanks to Eric Berger, Stacy Leeds, Thomas Mitchell, Richard Moberly, Colette Routel, John Snowden, Adam Thimmesch, William Whitford, Sandra Zellmer, and my research assistants, especially Nolt Nicholson, Ellen McKitterick, and Jerry Jefferson. I also appreciate helpful comments from the faculties of the University of Colorado-Boulder Law School, University of Oklahoma College of Law, University of Houston Law Center, and University of Cincinnati College of Law, on earlier versions of this work, and from the participants in Marquette University Law School's Junior Faculty Works-In-Progress Conference.

1. Leonard A. Carlson, Indians, Bureaucrats, and land: The Dawes act and the DECLINE OF INDIAN FARMING 80 (1981).
} 
contrary to both current federal Indian policy and the default rule for coownership in nearly every non-Indian context. A defining characteristic of common law co-ownership forms is the rule that all co-owners of land have an equal and undivided right to possess the entire estate, concurrently and presumptively, without the prior consent of their coowners and typically without any obligation to pay rent for that possession. ${ }^{2}$ The opposite rule has developed in Indian property gradually and through a series of mostly agency-level decisions that have not been the subject of any significant debate or discussion. ${ }^{3}$ Individual Indian owners have quietly lost their rights to use and possess jointly owned land despite repeated rounds of modern federal Indian statutes seeking to foster the opposite effect-Indian self-determination and Indian use of Indian land. ${ }^{4}$

Starting in 1887 with the General Allotment Act, Congress began to formalize a transition to Western forms of private property ownership within tribes' reserved territories. ${ }^{5}$ By forcing the uniform "allotment" of reservation land to individual Indians, Congress sought to break up tribes as a controlling social and political influence and to assimilate individual Indians into idealized versions of the agrarian, Jeffersonian farmer, all based on a belief in the transformative power of private property. ${ }^{6}$ Individual Indian allottees initially took title to their allotments not in a simple fee title but rather in a special trust status intended to prevent imprudent alienation of the land and to impose some preliminary federal oversight on individual land management decisions while the Indian allottees' intended transition to "civilized" farmer took effect.

Over time, allotment and the trust restrictions it imposed failed to create prosperous economies of individual farm proprietorships within tribal communities. Instead, patterns of pervasive co-ownership emerged on Indian allotments, with title to individually owned Indian land

2. See infra Part II

3. See infra Parts IV-V.

4. See, e.g., infra Part IV.A, B.4, C. This article treats use and possession rights somewhat interchangeably for this purpose, which is consistent with the Department of Interior's general practice to refer to these rights collectively as "owner's use" rights. However, of course, in some aspects of traditional property law use and possession rights are distinct; see also infra text accompanying note 259; $c f$. A.M. Honoré, Ownership, in OXFORD ESSAYS IN JURISPRUDENCE 107, 113, 116 (A.G. Guest ed., 1961).

5. General Allotment (Dawes) Act of 1887, ch. 119, 24 Stat. 388 (codified as amended at 25 U.S.C. $\S \S 331-334,339,341-342,348-349,354,381$ (2012)).

6. See Jessica A. Shoemaker, Comment, Like Snow in the Spring Time: Allotment, Fractionation, and the Indian Land Tenure Problem, 2003 WIS. L. REV. 729, 730, 749; Judith V. Royster, The Legacy of Allotment, 27 ARIZ. ST. L.J. 1, 9 (1995). 
becoming progressively fractionated as initial allotments passed, typically to multiple heirs, through a formulaic intestacy process and the restraints on alienation imposed by the federal trust status became permanent. Today, the majority of these remaining individual Indian allotments are co-owned by numerous (sometimes several hundred or more) co-owners, and most of these reservation lands are either leased to non-Indians through a Bureau of Indian Affairs (BIA) leasing program or are not used at all. This restrictive trust status also creates an enormous and expensive record keeping and administrative burden for the federal government. $^{7}$

To date, any serious discussions or scholarship regarding Indian land tenure (and Indian poverty more generally) have focused largely on two interrelated issues. The first is the practical problems of fractionation (e.g., the high transaction costs associated with having so many different co-owners). The second is the cumbersome federal trust system that restricts alienation of these fractional interests and otherwise imposes a cumbersome bureaucratic process on almost any land transaction. ${ }^{8}$ Therefore, proposed solutions have focused on how to consolidate fractional interests to reduce the total number of co-owners per tract, ${ }^{9}$

7. See, e.g., infra Parts III, IV.B.4, V.A.

8. Most trust property today still cannot be transferred, alienated, or leased without the approval of the Secretary of Interior. 25 U.S.C. $\$ \S 177,348,464,2216,2218$ (2012); see also 25 C.F.R. § 152.17 (2014). Some new exceptions for tribal leases of tribal lands now exist, but these do not apply to individually owned trust allotments. See, e.g., Helping Expedite and Advance Responsible Tribal Home Ownership (HEARTH) Act of 2012, Pub. L. No. 112-151, 126 Stat. 1150 (codified as amended at 25 U.S.C. $\S 415$ ).

By way of brief background, most Indian reservations today are characterized by a checkerboard of different tenure types within reservation boundaries. Land is now owned in essentially one of three categories. In the first category, the federal government holds significant portions of land in trust for the tribe itself ("tribal trust lands"). Land is also held, often by nonIndian owners who are not members of the governing tribe, in a traditional fee title. FELIX S. COHEN, HANDBOOK OF FEDERAL INDIAN LAW § 15.03, at 998-99 (Nell Jessup Newton ed., 2012) [hereinafter 2012 COHEN HANDBOOK]. A third category - and the subject of this article-is land held in trust by the federal government on behalf of individual Indian owners ("individual trust lands" or "allotments"). Id. at 1071.

9. See, e.g., Shoemaker, supra note 6 , at 764-70, $782-87$ (discussing and critiquing prior federal legislative consolidation efforts and arguing for flexible, equitable distribution of coownership interests at probate to promote case-by-case consolidation); Jered T. Davidson, Comment, This Land Is Your Land, This Land Is My Land? Why the Cobell Settlement Will Not Resolve Indian Land Fractionation, 35 AM. INDIAN L. REV. 575 (2011) (arguing for dormant interest termination solution); Brian Sawers, Tribal Land Corporations: Using Incorporation to Combat Fractionation, 88 NEB. L. REV. 385 (2009) (arguing incorporation model as solutions for co-owner cooperation); Anthony J. Franken, Student Article, Dealing with the Whip End of Someone Else's Crazy: Individual-Based Approaches to Indian Land Fractionation, 57 S.D. L. REV. 345 (2012) (arguing for estate planning solutions). 
and streamline or eliminate the federal trust bureaucracy itself. ${ }^{10}$ Little or no attention has been paid, however, to the fundamental rights that these individual Indian co-owners actually possess during life or how, given this fractionation, the individual entitlements and co-ownership institutions might be better designed to promote Indian use of Indian resources within the limits of the existing system. ${ }^{11}$

Indeed, so little attention has been paid to individual Indian landowners' actual legal rights to possession of their property (or lack thereof) that several legal authorities have relied on now-incorrect assumptions about Indian property rights or otherwise failed to recognize the modern changes taking place. These legal authorities include such bastions as the Supreme Court and the leading contemporary tribal membership organization and Indian law lobbying organization. For example, the Supreme Court has twice considered whether Indians' right to devise even the smallest fractional interests in these individual trust lands can be eliminated or significantly restricted, or whether doing so constitutes an unconstitutional taking of private property requiring just compensation to the individual property owner. ${ }^{12}$ While assessing the taking of this one property right - the right to devise - the Court noted that these landowners otherwise "retained full beneficial use of the property during their lifetimes" $" 13$ - but this is no longer true. Likewise,

10. Richard A. Monette, Governing Private Property in Indian Country: The Double-Edged Sword of the Trust Relationship and Trust Responsibility Arising out of Early Supreme Court Opinions and the General Allotment Act, 25 N.M. L. REV. 35 (1995) (arguing for tribal control of Indian property systems); Stacy L. Leeds, The Burning of Blackacre: A Step Toward Reclaiming Tribal Property Law, 10 KAN. J.L. \& PUB. POL'Y 491, 496-97 (2001) (arguing for a conversion from a federal trust to a tribal trust system); Stacy L. Leeds, Moving Toward Exclusive Tribal Autonomy over Lands and Natural Resources, 46 NAT. ReSOURCES J. 439, 455-61 (2006) (same); see also PROPERTY RIGHTS AND INDIAN ECONOMIES (Terry L. Anderson ed., 1992).

11. Many property law scholars and social scientists have recognized, in other contexts, the importance of carefully designing default rules for jointly owned property to promote co-owner cooperation and achieve the most efficient use of resources, while also satisfying personal, familial, and community goals. See, e.g., Hanoch Dagan \& Michael A. Heller, The Liberal Commons, 110 YALE L.J. 549 (2001) (arguing co-ownership default rules should encourage individual autonomy and self-governance while also providing an exit mechanism that maximizes cooperation); Thomas W. Mitchell, From Reconstruction to Deconstruction: Undermining Black Landownership, Political Independence, and Community Through Partition Sales of Tenancies in Common, 95 Nw. U. L. ReV. 505, 517-21 (2001) (discussing the role of partition rights in the problem of black farmer land loss); Sarah E. Waldeck, Rethinking the Intersection of Inheritance and the Law of Tenancy in Common, 87 Notre DAME L. REv. 737 (2011) (discussing the relevance of property rules for families seeking to maintain certain "identity property," such as a family cottage).

12. Babbit v. Youpee, 519 U.S. 234, 237 (1997); Hodel v. Irving, 481 U.S. 704, 717-18 (1987). The Court's takings analysis in these cases has been the subject of significant scholarly scrutiny. See, e.g., Michael A. Heller \& James E. Krier, Deterrence and Distribution in the Law of Takings, 112 HARV. L. REV. 997 (1999).

13. Hodel, 481 U.S. at 715. 
some property scholars have pointed to these fractionated individual Indian titles as an example of the anticommons problem by which too much ownership can result in under-utilization of a resource. ${ }^{14}$ These discussions, however, have largely not reflected that most Indian landowners are now legally precluded from directly utilizing the resource on their own. In some sense, the current issue on Indian lands is not a simple anticommons in which there is too much ownership, but rather a unique absence of the fundamental right of ownership - the right to possession-in any of the co-owners. Finally, even the National Congress of American Indians, the largest pan-Indian indigenous rights lobbying organization, expressed dismay and shock when the Department of Interior's most recent surface leasing regulations required a formal lease approved by the BIA (with an obligation to pay rent) even for co-owners taking possession of their own land-although this had arguably already been the Department's interpretation of individual Indians' property rights for roughly a decade. ${ }^{15}$

Analyzing the lack of individual rights to use and possess Indian land is particularly salient now. Congress and the Department of Interior are currently in the early stages of a ten-year effort to spend $\$ 1.9$ billion in settlement funds from the Cobell litigation to purchase some of these small fractional interests from willing sellers and return them to the governing tribe. ${ }^{16}$ If executed effectively, this fractional interest buy-

14. Michael Heller, The Gridlock Economy: How Too Much Ownership Wrecks MARKETS, STOPS INNOVATION, AND COSTS LIVES, 125-29 (2008); see also Dagan \& Heller, supra note 11, at 564 n.56; Michael A. Heller, The Tragedy of the Anticommons: Property in the Transition from Marx to Markets, 111 HARV. L. REV. 621, 685-87 (1998).

15. Comment of Jefferson Keel, President, Nat'l Cong. of Am. Indians, to Del Laverdure, Principal Deputy Assistant Sec'y of Indian Affairs (Jan. 30, 2011) at 2-3, http://www.regulations.gov/\#!documentDetail;D=BIA-2011-0001-0072 [hereinafter NCAI Comments]. Mr. Keel argued each landowner in a tenancy in common "has full rights to use the property in any manner" and is " "not liable for rent to the other co-tenant in the ordinary course of their relationship." Id. (quoting 1 FRIEDMAN ON LEASES 2:1.5 (Patrick A. Randolph ed., 2011)). $\mathrm{He}$ also noted there is "no authority in federal law for BIA to diminish the property rights of each Indian co-owner and to require co-owners to pay rent for the use of their own property." Id.; see also NAT'L CONG. OF AM. INDIANS, RES. PDX-11-015, HOMESITE LEASING, OWNER CONSENT AND THE INDIAN LAND CONSOLIDATION ACT (2011), http://www.ncai.org/attachments/Resolution_xrJM zVCyQhldPTtOSdUpYGKVSEXWbNqszNOGIORZReZWIxDQyya_PDX-11-015_final.pdf [hereinafter NCAI Resolution].

16. In 1996, Eloise Cobell famously filed a class action against the Secretary of Interior claiming the agency had violated its federal trust responsibility to Native American citizens by failing to account for billions of dollars in Indian trust assets, including income from individual trust lands. The federal courts generally agreed that the government had breached its trust responsibility, and the parties settled for $\$ 3.4$ billion. From these settlement funds, $\$ 1.9$ billion is allocated to purchasing small fractional interests from willing Indian sellers in order to reduce fractionation, which is seen as exacerbating the Department of Interior's accounting challenges. See Cobell v. Salazar, 679 F.3d 909, 913-16 (D.C. Cir. 2012); Cobell v. Salazar, 573 F.3d 808, 809 
back program could go a long way toward reducing the total number of co-owners in an average fractionated individual trust property to a more manageable number. Even a buy-back fund this large, though, is insufficient to eliminate fractionation and co-ownership completely. ${ }^{17}$ Nonetheless, as the number of co-owners per tract goes down, tribes must be supported in reevaluating local property rules. This is necessary not just to maintain any reduction in Indian land fractionation. It is also needed, more broadly, to create a more rational system of incentives and entitlements for individual co-owners to maximize all of the potential values of owning this resource, including the potential benefits of making some local, informal arrangements for the use and possession of land that may have important personal, social, and economic significances.

This article asserts that the current federal rules for Indian coownership of trust land are poorly designed and have erred too far on the side of the marginal interests of absentee landowners at the expense of the property rights of active local landowners whose direct use of their own jointly owned lands could have broader long-term benefits. This article proceeds in five parts. Part II begins with an analysis of the rules, and what we have learned, from traditional co-ownership frameworks in the non-Indian context. Part III discusses the specific context of this Indian law property problem. Part IV then provides an analysis of how Indian co-owner use and possession rights have been recognized and valued over time. This analysis will demonstrate that both historically and currently the intent of both indigenous nations and the federal government has been to promote Indian self-determination through Indian use of Indian land. Part IV also shows, however, that many federal actions in the twentieth century had perverse effects that did limit some owner's use rights. Picking up with regulatory changes in 2001

(D.C. Cir. 2009); Claims Resolution Act of 2010, Pub. L. No. 111-291, § 101, 124 Stat. 3064, 306670; Armen H. Merjian, An Unbroken Chain of Injustice: The Dawes Act, Native American Trusts, and Cobell v. Salazar, 46 Gonz. L. Rev. 609 (2011).

17. See, e.g., U.S. DeP'T OF THE Interior, Initial IMPLementation Plan: LAND Buy-BaCK PROGRAM FOR TRIBAL NATIONS 8 (2012), https://www.iltf.org/sites/default/files/BuyBack\%20Initial-Implementation-Plan.pdf [hereinafter BUY-BACK PLAN] ("[D]espite the size of the Fund, the Fund may not supply sufficient capital to purchase all fractional interests across Indian country."). Moreover, the plan applies only to willing sellers, and "it is not clear how many of the 219,000 individual owners will be interested in selling their fractional interests." Id. at 8 . There is also a time limit that precludes any purchases after 10 years. Id. There are also concerns that, as developed, costs of appraisals and other transaction costs could consume a significant portion of the funds. $I d$. at $11 \mathrm{n} .8$. 
and 2013, Part V analyzes the modern rule of no co-owner possession without a lease. Finally, Part VI identifies and addresses the particular challenges created by the current tenure system. This section concludes that the very property reforms originally intended to incentivize individual Indians' development of their own private properties have instead had the opposite effect, creating undue barriers to enterprise and self-determination in Indian Country. This article concludes that future co-ownership rules should be designed at the tribal level, with federal support, and with an emphasis on careful, locally driven modifications to the current co-ownership form to permit more diverse arrangements for land management and use among co-owners.

\section{DESIGN OF CO-OWNERSHIP RULES}

Where more than one owner has rights to concurrent ownership of the same land, the default property rules for these co-ownership arrangements outside of the Indian law context are relatively wellsettled. ${ }^{18}$ Whether the property is held in a tenancy in common, a joint tenancy with rights of survivorship, or a more specialized tenancy by entirety for married persons, the defining characteristic is that all coowners, regardless of the size of their fractional share, have an undivided right to possess the whole property. ${ }^{19}$ Co-owners share most of the other benefits and burdens of their co-ownership in proportion to their respective interests in the property. For example, each co-owner is ultimately responsible for a pro rata share of the carrying cost of the property and, likewise, is entitled to a pro rata share of the value when it is sold. ${ }^{20}$ Co-owners are also entitled to a pro rata share of most other income derived from the property, whether from extracting natural resources or leasing the property to third parties who pay rent for its use. $^{21}$ But with respect to possession and use of land by co-owners themselves, "no matter how small [an individual's] fractional interest, each [co-owner] is entitled to full possessory rights in every part of [the property], subject only to fellow co-tenants' identical rights of possession." 22

18. See generally 7 Richard R. POWELl, POWELl On REAl PROPERTY § 50.01-.09 (Michael Allen Wolf ed., 2013).

19. Id. $\S 50.01[1]$ at 4; see also 86 C.J.S. Tenancy in Common $\S \S 1,26$ (2014).

20. 86 C.J.S. Tenancy in Common $\S \S 1,90$.

21. 2 AMERiCAN LAW OF Property $\S 6.14$ (A. James Casner ed., 1952).

22. Evelyn A. Lewis, Struggling with Quicksand: The Ins and Outs of Co-tenant Possession Value Liability and a Call for Default Rule Reform, 1994 WIS. L. REV. 331, 347; see also 7 POWELL, 
This undivided right to possess the whole property is important and broad. A co-owner in possession of jointly-owned land, under these default rules, need not get any kind of consent or permission from her coowners before taking that possession. ${ }^{23}$ In addition, in most jurisdictions, when a single co-owner initiates sole and exclusive possession of the entire property and the remaining co-owners make no attempt to use the property simultaneously, the in-tenant in possession is not liable to her absent co-owners for any kind of rent for her ongoing use of their jointly owned land. ${ }^{24}$ The in-tenant is really exercising her own property right to possess the whole and is not required to pay for that exercise where the other co-owners fail to make use of their own rights. ${ }^{25}$ In some cases, courts also explain this no-rent rule based on the legal conception that all the co-owners in a joint tenancy, for example, are really just one single legal owner. ${ }^{26}$ Thus, possession by one co-owner is conceived as equivalent to possession by all of the co-owners. ${ }^{27}$

The rights of a co-owner to use the property without compensating the other co-owners are limited only in a case where a co-owner receives actual rental income from a third party for leasing out the property. ${ }^{28} \mathrm{~A}$ co-owner does typically have to share actual rental proceeds with his coowners, even though he could have used the same land himself directly as a co-owner without a rent requirement if he did not interfere with any other co-owner's actual use. ${ }^{29}$

supra note $18, \S 50.01[1]$

23. W.W. Allen, Annotation, Accountability of Cotenants for Rents and Profits or Use and Occupation, 51 A.L.R.2d $388 \S 9$ (1957) (updated 2014); see also 20 AM. JUR. 2D Cotenancy and Joint Ownership § 115 (2014).

24. 7 POWELL, supra note $18, \S 50.03[1]$ [a]; Allen, supra note $23, \S \S 2,7[\mathrm{a}]$; CORNELIUS MOYNIHAN \& SHELDON F. KURTZ, MOYNIHAN's INTRODUCTION TO THE LAW OF REAL PROPERTY 283 (4th ed. 2005) ("All of the cotenants are free to enjoy their ownership and the non-occupying coowners should not, by abstaining from the exercise of their right to possession, be able to convert the status of the occupying tenant from that of co-owner to rent paying tenant.").

25. See Roger Bernhardt \& Ann M. Burkhart, Real Property in a Nutshell (West 6th ed. 2010).

26. E.g., Swafford v. Brasher, 22 So.2d 24, 25 (Ala. 1945) ("The possession of one tenant in common is prima facie presumed to be the possession of all ....").

27. 86 C.J.S. Tenancy in Common $\S 27$ (2014); see also Swafford, 246 Ala. at 638; Big Run Coal \& Clay Co. v. Helton, 323 S.W.2d 855, 856 (Ky. Ct. App. 1959) ("The possession of one cotenant is presumptively the possession of all and inures to the benefit of all."); Shives v. Niewoehner, 191 N.W.2d 633, 635 (Iowa 1971) ("The possession of one tenant in common is presumed to be for the benefit of all, and will, in the absence of statute to the contrary, be regarded as the possession of all cotenants ....").

28. 2 AMERICAN PROPERTY, supra note $21, \S 6.14$.

29. 7 Powell, supra note $18, \S 50.04[1]$, at 22; Swartzbaugh v. Sampson, 54 P.2d 73, 75 (Cal. 
For this and other reasons, some scholars have critiqued the rule that a single co-owner in possession need not compensate the out-ofpossession co-owners for the value of her own use and possession of the jointly owned land. ${ }^{30}$ These critics have suggested, for example, that the non-possessing co-owners may be entitled to some measure of compensation from the in-tenant out of fairness for her exclusive use and possession of their land, even if she is a fellow co-owner. ${ }^{31}$ However, although the possibility of a rent requirement has been debated, and in a minority of jurisdictions adopted,$^{32}$ the fundamental right of possession is left largely unquestioned, probably for the same reason that possession itself is deemed one of the most important sticks in the property rights bundle. $^{33}$ Without the right to possess one's own property, it hardly seems like property at all. And for co-ownership of property to mean something, it must include the right to possess the property, at least in parallel with other co-owners. ${ }^{34}$

The Supreme Court, for example, has underlined this point by emphasizing that "property law has long protected an owner's expectation that he will be relatively undisturbed at least in the possession of his property." ${ }^{35}$ The Supreme Court has also emphasized that any permanent physical occupation of another's property "does not

Ct. App. 1936); see also Stark v. Barrett, 15 Cal. 361, 368 (1860).

30. E.g., Lewis, supra note 22, at 352, 419 ("[A]n in-tenant's exclusive use of cotenancy property is a combination of actual possession on his own behalf and representational possession of the interest attributable to the out-tenant. Given this, it is anomalous and intellectually inconsistent to say that the unity of possession concept requires value accountability for representational possession through a third-party stranger to the cotenancy, but prevents such value accountability when the representational possession is achieved through a non-stranger cotenant."); Lawrence Berger, An Analysis of the Economic Relations Between Cotenants, 21 ARIZ. L. REV. 1015 (1979).

31. Lewis, supra note 22, at 418.

32. Id. at app. (listing minority of states that have adopted a default rent requirement for coowner use); see also Cohen v. Cohen, 106 N.E.2d 77, 79 (Ohio 1952). It is also worth noting that, although not requiring rent per se, in many cases courts will require an in-tenant in sole possession to pay an increased or disproportionate share of the carrying or maintenance costs of the property, up to and including the value of that tenant's possession itself. See, e.g., 2 AMERICAN Property, supra note $21, \S 6.17$, at 76 .

33. Honoré, supra note 4, at 113 (arguing that "[u]nless a legal system provides some rules and procedures for attaining [the right to possess] it cannot be said to protect ownership").

34. Others have characterized this by stating that the distinctive feature of property is the right to exclude others - to take possession yourself and prevent others from doing so. In the case of coownership, co-owners generally can exclude non-owners, but not other co-owners, because all coowners have an essential right to possession of the whole. James E. Krier, Essay, Evolutionary Theory and the Origin of Property Rights, 95 CORNELL L. REV. 139, 144 (2009) ("If nobody has a right to exclude, there is no property.").

35. Loretto v. Teleprompter Manhattan CATV Corp., 458 U.S. 419, 436 (1982). 
simply take a single 'strand' from the 'bundle' of property rights: it chops through the bundle, taking a slice of every strand" because the owner neither has the right to possess the occupied space himself nor to exclude the occupier from the possession and use of that space. ${ }^{36}$ The Supreme Court has also framed the importance of a landowner's right to exclude non-owners - which is really the right to possess the property while prohibiting outsiders from taking possession of the property-as "one of the most essential sticks in the bundle of rights that are commonly characterized as property ....",37

As a practical matter, obvious challenges and conflicts can arise when co-owners share the same right to possess (simultaneously) the whole. As one court evocatively described, "[t]wo men cannot plow the same furrow." 38 Thus, two key remedies have been created for disputes among co-owners in the common law: partition and ouster. Partition gives every co-owner in a tenancy in common or joint tenancy the right to bring an action to force physical division of co-tenancy property so that each co-owner can have sole ownership of a separate, divided piece of property. ${ }^{39}$ If physical in-kind partition is not feasible under the circumstances, the court may force a sale of the property and division of the proceeds among former co-owners in proportion to the economic interests held. ${ }^{40}$ This unilateral right to force a partition provides an absolute right to exit from the joint ownership. ${ }^{41}$

Ouster is a narrower remedy, short of partition, for co-owners who disagree about how the property should be used. If a co-owner in possession actually excludes another co-owner from taking shared

\footnotetext{
36. Id. at 435 .

37. Kaister Aetna v. United States, 444 U.S. 164, 176 (1979). Certainly, this does not mean that property requires absolute rights to exclude. See, e.g., Prune Yard Shopping Ctr. v. Robins, 447 U.S. 74 (1980) (private shopping mall may not exclude certain protesters exercising protected rights to speech); State v. Shack, 277 A.2d 369 (N.J. 1971) (private farmer employing and housing migrant farmworkers may not exclude specialized service providers who are "essential" to those workers" "health, welfare, or dignity").

38. Mastbaum v. Mastbaum, 9 A.2d 51, 55 (N.J. Ch. 1939).

39. 7 PoweLL, supra note $18, \S 50.07[1]$, at 37 .

40. Id.

41. See id.; 4 James A. Blackmun et al., Thompson On Real Property $\S 30.02$, at 82 (David A. Thomas ed., 2004); Waldeck, supra note 11, at 737; Thomas W. Mitchell et al., Forced Sale Risk: Class, Race, and the "Double Discount," 37 Fla. St. U. L. REv. 589, 610 (2010). The National Conference of Commissioners on Uniform State Laws has also addressed the subject by completing the Partition of Heirs Property Act, which as of this writing has been enacted in three states and is being considered in four more. See generally Partition of Heirs Property Act, UNIF. LAw. COMM'N, http://www.uniformlaws.org /Act.aspx?title=Partition\%20of\%20Heirs\%20Property \%20Act (last visited Nov. 20, 2014) (describing the Uniform Partition of Heirs Property Act and noting the status of its enactment across the United States).
} 
possession of the property - that is, physically prevents another co-owner from actual efforts to use or possess any part of the land - there may be sufficient evidence of "ouster." "42 Typically, to find ouster there must be evidence that the non-possessing co-owner "actually sought to occupy the [property] but was prevented from moving in by [the possessing coowner]. ${ }^{, 43}$ In most jurisdictions, this requires more than just a demand from other co-owners to vacate the property or pay rent for its use. ${ }^{44}$ If there is ouster, the remedy is to require the possessing co-owner to pay a fair-market rental value to the excluded co-owners. ${ }^{45}$

The combined effect of these joint ownership rules is to reward and encourage productive use of property by the owners themselves. ${ }^{46}$ An industrious co-owner can take complete possession of jointly owned land without any obligation to get prior permission for his use or possession from his co-owners, ${ }^{47}$ and if the other absentee co-owners make no parallel effort to use and possess the land themselves (and therefore are never deemed to be "ousted" by the in-tenant), the industrious in-tenant has no obligation to compensate his co-owners for his use. ${ }^{48}$ However, an in-tenant who makes direct use of the land itself is rewarded not only with free rent to the entire property but also with some protection in partition or other accounting or contribution proceedings. For example, if an in-tenant has individually improved the property or is in current possession of the property, that history of productive use and possession, and personal attachment to the land, is typically considered and, where

42. MOYNIHAN \& KURTZ, supra note 24, at 282 ("Since each of the tenants is entitled to possession of the entire property subject to a reciprocal right in his cotenants, if one of the tenants excludes the others from the possession or enjoyment of the whole or any part of the land, his conduct amounts to an ouster and an action of ejectment will lie in favor of the excluded tenants.").

43. Spiller v. Mackereth, 334 So. 2d 859, 862 (Ala. 1976).

44. See Allen, supra note 23, § 9; see also MoyniHAN \& KURTZ, supra note 24, at 282 ("Sole possession by the occupying tenant ... without more, is not ouster. There must be a repudiation of the rights of the cotenants and a claim of sole ownership; otherwise, the cotenants may properly assume that the possession of the occupying tenant is not hostile to their interests.").

45. 7 POWELL, supra note $18, \S 50.03[1][\mathrm{a}]$, at $15-16$.

46. The wisdom of encouraging owners to use their own land, especially for farming, rather than leasing it to third parties, has theoretical support. See, e.g., DAVID J. PETERS, Mo. ECON. RES. \& Info. Ctr., Technical Paper P-0702-1, Revisiting The Goldschmidt Hypothesis: ThE EFFECT OF ECONOMIC STRUCTURE ON SOCIOECONOMIC CONDITIONS IN THE RURAL MidWEST 7-8 (2002) (summarizing social science demonstrating rural communities dominated by locally owned, moderate-sized farms consistently have better socioeconomic well-being across multiple indicators than communities with agriculture dominated by large, corporate or absentee farm ownership).

47. Co-owners cannot, of course, commit waste or unreasonably prejudice the interests of coowners. See generally 7 PowELL, supra note 18, $\S 56.01-56.12$; see also infra Part VI.A.1.

48. This is not the same if he merely leases the property to a third party. See supra note 29 and accompanying text. 
possible, accounted for in the ultimate distribution of land or other monetary proceeds from the land. ${ }^{49}$

\section{WHY OWNER'S USE RIGHTS MATTER}

The situation in nearly every Indian community today is essentially the opposite of the default rules for other co-owners of property. Coowners of individually owned Indian trust land no longer have a direct, undivided right to possess their property. Nor can they possess some proportionate share of their land. Instead, an Indian co-owner must execute a formal lease, or otherwise get actual prior permission from all of their co-owners, and often approval from the BIA, before taking possession. They must also pay those other co-owners fair-market-value rent (as determined by the BIA, typically after a lengthy appraisal process) in exchange for that possession. There is no parallel functioning partition remedy to exit the property unilaterally and directly, and in effect, all co-owners are "ousted" from their jointly owned property by the Department of Interior's property rules themselves. ${ }^{50}$

In 2001, the Department of Interior promulgated the first regulation openly declaring that only an "Indian landowner who owns 100 percent of the trust or restricted interests in a tract" is allowed to "take possession without a lease or any other prior authorization from [the BIA]." ${ }^{51}$ In

49. 7 POWELL, supra note $18, \S 50.04$ [2], at 24; 4 BLACKMUN, supra note $41, \S 32.07(\mathrm{~b})$, at 102. The in-tenant, however, may have to pay more of the costs of carrying and maintaining the property, and in that way offset somewhat his "free use" of the co-owners" shares of the land. Id.

50. In 2004, Congress did authorize a partition sale option for some "highly fractionated Indian lands," but partition has a different meaning here, which illustrates again some of the complexity of the Indian trust bureaucracy. 25 U.S.C. $§ 2204(c)$ (2012). Instead of providing a unilateral exit right, with a preference for partition in kind, the current partition sale rules provide for a particular kind of forced sale of highly fractionated parcels after a detailed application process, consent from at least 50 percent of co-ownership interests in the land, and a mandatory appraisal. Id. The sale must also take place at an auction with limits on who qualifies for potential bidding and with the caveat that the final price at auction must be at least the appraised value. Id. This cumbersome practice rarely occurs in practice. Diane K. Lautt, The American Indian Probate Reform Act: A Five-Year Review, 51 WASHBURN L.J. 105, 119-20 (2011). In addition, the Department of Interior technically does have some other in-kind partition authority, but it is outdated and also rarely used. See generally 2012 COHEN HANDBOOK, supra note 8, at 1085-86; see also 25 C.F.R. $§ 152.33$ (2014) (discussing different partition procedures for "competent" versus "incompetent" co-owners); 25 U.S.C. $\S \S 372,378,483$ (2012); see also S. REP. No. 106-361, at 2 (2000) ("Even when partition [in kind] is a legal option, it is rarely a practical alternative."); Walker v. Great Plains Reg'l Dir., Bureau of Indian Affairs, 57 I.B.I.A. 167, 169, 174-77 (2013) (discussing federal legal authority for partition in kind of trust allotments in context of a nearly 20-year (and still unsuccessful) effort by one individual co-owner to have a pro-rata share of his allotment interest partitioned to him).

51. 25 C.F.R. $\S \S 162.104(a), 166.200$ (2002). However, in some instances, even a sole owner still needs BIA permission to make certain uses of his or her own land. See, e.g., Koontz v. Nw. Reg'1 Dir., Bureau of Indian Affairs, 55 I.B.I.A. 177, 185 (2012) ("Indeed, even where a trust 
2013, the Department expanded the application of this no-possession rule to say that before a co-owner could possess her own land she must have a formal BIA-approved lease or some other form of unanimous permission from all of her co-owners. ${ }^{52}$ Unauthorized possession, even by a coowner, would be - and is - treated as trespass by the BIA. ${ }^{53}$

These rules create perverse results where individual Indian landowners are precluded from making actual use of their own landwhether for housing, farming, gardening, grazing, business, or other purposes. As just one example, at the Pine Ridge Reservation in South Dakota, approximately 1 million of the 1.7 million reservation acres are still owned by individual Indians. ${ }^{54}$ Despite this significant land resource, Pine Ridge had the poorest census tract in the nation and an unemployment rate of 73 percent. ${ }^{55}$ A year after President Clinton's visit in 1999 to announce additional federal support, there were still approximately 1200 families on a waiting list for housing on the Pine Ridge Reservation. ${ }^{56}$ More recently, when a group of three Pine Ridge families successfully started a sustainable buffalo ranching cooperative on the reservation, they expressly desired to expand their operation to include more Pine Ridge families. Despite market demand for such an expansion, this growth was precluded due, at least in part, to the

allotment is owned entirely by one individual, that individual must also secure approval from BIA for any harvest on the allotment if the forest products will be sold."); see also 25 C.F.R. § 163.27 (2014) (requiring BIA approval even for harvest of forest products for personal use).

52. 25 C.F.R. $\$ 162.005$ (2014).

53. Id. $\S 162.003$ (defining trespass as "any unauthorized occupancy, use of, or action on any Indian land or Government land"). But see id. § 162.106 and infra note 256 and accompanying text for possible special rules for agricultural leases. The BIA also in some instances exercises more flexibility in how a "trespassing" co-owner is treated. E.g., Goodwin v. Pac. Reg'l Dir., Bureau of Indian Affairs, 44 I.B.I.A. 25, 29-30 (2006) (holding that co-owner in trespass need not be immediately evicted from premises but rather BIA could elect to allow co-owner to remain in possession while a possible residential lease is considered).

54. Village Earth, Pine Ridge Reservation Allottee Land-Planning Map Book 3 [hereinafter PINE RIDGE MAP BOOK], https://www.iltf.org/sites/default/files /pine_ridge_map book.pdf; see also Pine Ridge Land Information System, VILlaGE EARTH, $\overline{\mathrm{h}} \mathrm{ttp}: / / \mathrm{www}$. lakotalands.net/prlis (last visited Nov. 20, 2014).

55. Clinton Visits Indian Reservation, NewSDAY, July 8, 1999, at A07.

56. U.S. Dep't of Hous. \& Urban Dev., Shared Visions: Pine Ridge, A Year later SHARING THE DREAM 12 (2000), http://archives.hud.gov/reports/pineridge/sharedvisions.pdf. In 2013, the Chief Executive Officer of Oglala Sioux (Lakota) Housing agency on the Pine Ridge Reservation told the Senate Indian Affairs Committee that Pine Ridge needs at least 4,000 new housing units to meet community needs. Identifying Barriers to Indian Housing Development and Finding Solutions: Hearing Before the S. Comm. on Indian Affairs, 113th Cong. 30-33 (2013) (statement of Paul Iron Cloud, Chief Executive Officer, Oglala Sioux (Lakota) Housing, Pine Ridge Reservation). 
ranchers' lack of access to their own lands for grazing. ${ }^{57}$ Instead, a small group of just 20 people lease 46 percent of Pine Ridge Indian lands through the BIA's leasing program, ${ }^{58}$ and individual landowners are effectively prohibited from accessing their own jointly owned lands without a lease. $^{59}$

The experience on Pine Ridge reflects the general experience in many Indian communities. Although roughly 56 million acres of Indian land remain within Indian reservation boundaries today, and more than 10 million of these acres are owned by individual Indians in this trust status, ${ }^{60}$ extreme poverty persists in many Indian communities. ${ }^{61}$ The vast majority of Indian land is agricultural, ${ }^{62}$ and agriculture provides one of the best non-gaming opportunities for growth of tribal economies. ${ }^{63}$ Yet, Indians themselves do not typically use these agricultural lands. Only 16 percent of the $\$ 1.6$ billion worth of agricultural commodities produced on Indian reservations in 2007 went to Native farmers and

57. See Alleen Brown, This Land is Our Land, IN THESE TIMES (July 12, 2011), http://www.iatp.org/documents/landowners-without-land; see also Lakota Buffalo Caretakers Cooperative, VILLAGE EARTH, http://villageearth.org/global-affiliates/lakota-buffalo-caretakersassociation (last visited Nov. 20, 2014).

58. PINE RIDGE MAP BOOK, supra note 54, at 3.

59. See infra Part V.

60. BuY-BACK Plan, supra note 17 , at 5 ; see also GEORGE L. RUSSEL, AMERICAN INDIAN DIGEST 30 (1993) (approximately 300 federally recognized reservations include 55 million acres of Indian-owned land; 44 million acres are held in trust for the tribe, while the remaining 11 are individually owned).

61. U.S. COMM'N ON Civil Rights, A Quiet CRISIS: Federal Funding AND UnMET NEedS IN INDIAN COUNTRY ix (2003) [hereinafter QUIET CRISIS], http://www.usccr.gov/pubs/na0703 /na0731.pdf. For example, the United States Commission on Civil Rights has concluded that "Native Americans continue to rank at or near the bottom of nearly every social, health, and economic indicator," compared to other groups in American society, suffering "higher rates of poverty, poor educational achievement, substandard housing, and higher rates of disease and illness." Id.

62. RUSSEL, supra note 60 , at 30 (stating that of the 55 million acres of land contained within federally recognized Indian reservations, 44 million Indian acres are range and grazing lands, 5.3 million acres are commercial forest, and 2.5 million acres are crop lands); Darla J. Mondou, The American Indian Agricultural Resource Management Act: Does the Winters Water Bucket Have a Hole in It?, 3 DRAKE J. AGRIC. L. 381, 387 (1998) (stating 75 percent of Indian land is agricultural); Judith V. Royster, Practical Sovereignty, Political Sovereignty, and the Indian Tribal Energy Development and Self-Determination Act, 12 LEWIS \& CLARK L. REV. 1065, 1066 n.3 (2008) (reporting that "more than 43 million acres of tribal lands are range and grazing land, and another 2.5 million acres are "crop areas"').

63. See S. REP. No. 103-186, at 2 (1993), reprinted in 1993 U.S.C.C.A.N. 2459, 2460 (finding that "[t]he farming and ranching sector provides the main source of entrepreneurial opportunity to the Indian people within Indian reservations and communities"); see also William Parker, Agriculture, in AMERICAN ECONOMIC GROWTH: AN ECONOMIST's HistoRY OF THE UNITED STATES 409 (Lance Davis et al. eds., 1972). 
ranchers. ${ }^{64}$ The Department of Interior recently estimated that half of all the jointly owned individual Indian land on reservations was idle or "generated no income" from 2006 to 2011 . $^{65}$

Meanwhile, fresh food is in short supply on many reservations, ${ }^{66}$ as is housing ${ }^{67}$ and employment. ${ }^{68}$ When the Indian Land Tenure Foundation (ILTF) conducted surveys to measure "how Indian people view ... land ownership and management," ILTF discovered that "overall, the respondents [74.31 percent of them] perceived Indian control and management of land as having the most importance in securing a better life for future generations and tribal sovereignty." ${ }^{\circ 9}$ However, the survey revealed that "in reality, property rights are not, or cannot be, used effectively in Indian country. In other words, the respondents perceived great systemic barriers in the use of property rights related to land and natural resources."

64. Raymond Cross, Keeping the American Indian Rancher on the Land: A Socio-Legal Analysis of the Rise and the Demise of American Indian Ranching on the Northern Great Plains, 49 WASHBuRn L.J. 745, 769-70 (2010); U.S. DEP'T OF AGRIC., 2007 CENSUS OF AGRICUltuRE: AMERICAN INDIAN FARMERS 1, 3 (2009) [hereinafter 2007 CENSUS].

65. BUY-BACK PLAN, supra note 17, at 5-6.

66. See, e.g., Kelly Gibson, Fresh Food for Food Deserts, NAT'L Relief Charities Blog (Aug. 5, 2011), http://blog.nrcprograms.org/fresh-food-in-food-deserts (describing charitable efforts to provide fruits and vegetables to isolated reservations); Steph Larsen, Welcome to the Food Deserts of Rural America, GRIST.ORG (Jan. 22, 2011, 10:00 PM), http://grist.org/article/2011-01-21welcome-to-the-food-deserts-of-rural-america (describing one experience of a food desert on Omaha Indian Reservation in Nebraska). Compare Food Access Research Atlas, U.S. DEP'T OF AGRIC. ECON. RESEARCH SERV. (May 28, 2014), http://www.ers.usda.gov/data-products/food-accessresearch-atlas/go-to-the-atlas.aspx\#.UyYms31NxBU, with Indian Reservations in the Continental United States, NAT'L PARK SERV., U.S. DEP'T OF THE INTERIOR, http://www.nps.gov/ nagpra/DOCUMENTS/RESERV.PDF (last visited Nov. 20, 2014).

67. Despite relatively widespread landownership, less than a third of Native Americans own homes (compared to two-thirds of all Americans). U.S. GOV'T ACCOUNTABILITY OFFICE, GAO-02654, NATIVE AMERICAN HOUSING: VA COULD ADDRESS SOME BARRIERS To PARTICIPATION IN DiRECT LOAN PROGRAM (2002). HUD has also estimated that housing shortages for Indian families increased 40 percent from 2003 to 2012. See Identifying Barriers to Indian Housing Development and Finding Solutions: Hearing Before the Senate Committee on Indian Affairs, 113th Cong. 1 (2013) (statement of Cheryl H. Causley, Chairwoman, National American Indian Tribal Council).

68. QUIET CRISIS, supra note 61. More recent reports have suggested unemployment for Indians who live on reservations may be "nearly ten times that for the nation as a whole." Gavin Clarkson, Accredited Indians: Increasing the Flow of Private Equity into Indian Country as a Domestic Emerging Market, 80 U. Colo. L. Rev. 285, 287 (2009).

69. Community Survey: Importance and Value of Property Rights, 2003 INDIAN LAND TENURE FOUND. 1, 3-4, available at https://www.iltf.org/sites/default/files/community_survey_2003.pdf. Only 44.5 percent said property rights "work for Indians." Id. Only 15.1 percent thought their property rights were secure and respected by federal and state governments, and 16.1 percent perceived information about property rights as "accessible and understandable." Id. at 4.

70. Id. 
Previously, I have argued that the extreme fractionation on Indian lands, combined with the correspondingly restrictive federal trust status over these lands, has caused what I termed a "constructive dispossession" within Indian Country, with Indian landowners retaining few, if any, of the beneficial aspects of property ownership under these conditions. $^{71}$ Other property scholars in the anticommons literature have also pointed to the under-utilization of these lands and blamed the problem on a presumed presence of too many property rights, and therefore too many transaction costs, for individual owners to choose to invest in their own land's use. ${ }^{72}$ Certainly, the extreme degree of fractionation and the burdensome federal trust status do impede land use. However, Indian landowners' lack of any direct use and possession rights is at least another significant-and overlooked-factor. Fractionation and the trust bureaucracy are two important elements of the Indian land tenure dilemma; the actual design of owners' legal rights and entitlements is the critical third point in the triangle. In other words, it is not only that Indian landowners suffer a constructive dispossession because of an on the ground over-crowding and over-bureaucratization of small interests. Rather, current Department of Interior rules now effectuate a legal dispossession, too. It is not merely inconvenient for Indian landowners to use and possess their lands. In many cases, it is also illegal.

This legal dispossession is not explained away by some kind of special wrinkle of federal Indian law and history. Instead, the opposite is true. Historically, individual Indian property rights, especially individual Indian possession rights, were recognized and even promoted by the federal government. ${ }^{73}$ Congress, more recently, continues to pass legislation seeking to increase Indian landowners' use and control of their land. ${ }^{74}$ The Supreme Court has also held that, even in the cases of the most extreme fractionation, Indian landowners retain valid protected private property rights in these tiny interests, and even just one "stick" in the individual Indian landowners' property rights "bundle" - the right to devise these small interests - could not be eliminated, or overly

\footnotetext{
71. Shoemaker, supra note 6 , at $730 \& \mathrm{n} .5$; see also Sawers, supra note 9 , at 404 (incorporating term); see also Indian Land Consolidation Act: Hearing Before the S. Comm. on Indian Affairs on S. 1340, 117th Cong. 34 (2002) (statement of Austin Nunez, Chair of Indian Land Working Group) (telling Senate Indian Affairs Committee that Indian landowners "will no longer stand" for the experience of being "detached from our lands as your laws have tried to make us").

72. See supra note 14 and accompanying text.

73. See, e.g., infra Part IV.A.

74. See infra Part IV.A.3-4, IV.C.
} 
restricted, without just compensation under the Fifth Amendment. ${ }^{75}$ Nonetheless, the default co-ownership rules have changed inversely to prohibit direct individual use. In order to appreciate the significance of this change, the next section analyzes the repeated reaffirmations of the importance of individual use and possession rights by the federal government and the strength of these rights historically. Although European contact, discovery, and the conquest story all had a massive dispossession effect on Indian owners of Indian land as huge swaths of Indian property and territory transferred to non-Indian ownership and control, the legislation of the last century and a half points to a Congressional preference for (or at least policy of non-interference with) Indian possessors and users of remaining Indian land.

\section{THE EBB AND FLOW OF INDIAN OWNER's USE}

Prior to contact with Europeans, individual Indians' rights in land were defined by the hundreds of different indigenous nations that existed on this continent. ${ }^{76}$ Each of these nations had their own internal, functioning institutions for the organization and management of individual property rights. ${ }^{77}$ This section provides an overview of these indigenous land tenure systems, with a focus on how they valued individual use rights, and then analyzes the evolution of these rights following Indian nations' contact with Europeans. At least on the lands that Indian nations retained after contact, the federal government has repeatedly recognized and even promoted strong individual use and possession rights. Although some individual Indian landowners certainly experienced challenges in exercising these use and possession rights, and intermittent agency actions limited some of these rights to some degree, the overall theme is preference and protection for owner's use and possession rights in Indian lands.

75. Babbit v. Youpee, 519 U.S. 234, 237 (1997); Hodel v. Irving, 481 U.S. 704, 717-18 (1987).

76. See generally Indian Entities Recognized and Eligible to Receive Services from the Bureau of Indian Affairs, 77 Fed. Reg. 47868 (Aug. 10, 2012) (current listing of 566 federally recognized Indian tribes).

77. See also Kenneth H. Bobroff, Retelling Allotment: Indian Property Rights and the Myth of Common Ownership, 54 VAND. L. REV. 1559 (2001); Leeds, Burning, supra note 10, at 493; John C. Hoelle, Comment, Re-Evaluating Tribal Customs of Land Use Rights, 82 U. CoLo. L. ReV. 551 (2011). 


\section{A. Prior Possession}

\section{Indigenous Systems of Individual Use}

The nuances of indigenous property law institutions varied by tribe, and they were necessarily informed by both the unique landscape in which each tribe was located and basic differences in social structures, such as whether a given tribe engaged primarily in settled farming or more nomadic hunting. Generally speaking, most of these indigenous property law institutions included at least some allocations of individual use rights. Although sometimes generalized in collective understanding as a historic communal or commons-ownership regime, in fact most original (pre-European contact) tribal land tenure systems consisted of indigenous institutions for the allocation of individual use and occupancy rights to tribal members based on an individual's actual, continuous use of a particular piece of land. ${ }^{78}$ Thus, indigenous tenure was based not on true commons systems but instead on systems of individual use and occupancy rights, with individual Indians enjoying specific rights in land as perfected by actual use. ${ }^{79}$ These individual use and occupancy rights, generally, would revert back to the tribe upon abandonment by the individual property holder. ${ }^{80}$ For example, early accounts of the Omaha Tribe in Nebraska report institutions for family-based gardening and farming that provided for undisturbed ownership and occupancy of tracts of lands for as long as a family cultivated that land. ${ }^{81}$ This came with a collective understanding that such land would become free for use by other tribal members again only once the tract had been abandoned for a season. ${ }^{82}$

To the extent there was shared ownership or shared rights to use a given piece of property (e.g., where multiple family members jointly farmed a particular plot of land), these indigenous tribal property systems

78. Hoelle, supra note 77 , at 559-60. Almost all Indian property systems permitted tribal citizens to transfer their individual use and possession rights within the tribe but prohibited transfers outside of the tribe without tribal leaders' permission. Bobroff, supra note 77, at 1572. This restriction on alienation outside the tribe "led many outsiders, including nineteenth and twentiethcentury reformers, to conclude that title to Indian lands was invariably held by the tribe in common," but this was not true. Id.; see also CARLSON, supra note 1, at 85.

79. History of the Allotment Policy: Hearings on H.R. 7902 on the Readjustment of Indian Affairs Before the H. Comm. on Indian Affairs, 73d Cong. 431 (1934) (statement of D.S. Otis) [hereinafter Otis].

80. Bobroff, supra note 77, at 1584.

81. Addison E. Sheldon, Land Systems and Land Policies in Nebraska: A History of NEBRASKA LAND 5 (1936).

82. Id. 
also included "basic rules" by which these jointly owned lands were managed among the co-owners. ${ }^{83}$ For example, in the Cherokee tradition, Dean Stacy Leeds has reported that these internal "rules" provided preferences for the decisions of active owners who remained physically connected to the land. ${ }^{84}$ They also imposed a requirement that any co-owners who permanently moved away from the area or no longer maintained a meaningful contact with the property would sell or gift their interests to another remaining active co-owner. ${ }^{85}$ Indeed, any sale offers were made to co-tenants or other Indian family members, not to outsiders, and one co-tenant could not change the land's use without consensus of the other active co-owners. ${ }^{86}$

\section{Discovery and Recognized Occupancy Rights}

Of course, European contact with indigenous nations resulted in a fundamental restructuring of Indian land tenure patterns. These changes started at a macro level with the introduction of European settlers causing a shift of tribal territorial boundaries - and therefore an actual geographic change to location and size of particular landholdings. Over time, however, European contact changed not just the map of where tribal landholdings were located but also the internal allocations of individuals' rights to these lands. Initially, however, the use and possession rights of individual Indians were still primarily protected.

In Johnson $v$. M'Intosh, the Supreme Court concluded that "discovery" of the new continent by Europeans resulted in the transition of Indian land tenure from its pre-contact fee-like status to an Indian "right of occupancy" that was extinguishable only by the new European sovereign, either through a purchase between the sovereign European nation and the sovereign Indian nation, or by conquest. ${ }^{87}$ This

83. Leeds, Burning, supra note 10, at 496.

84. Id.

85. $I d$.

86. Id. In addition, before allotment, any individual Indian rights in land passed by tribal inheritance systems, which varied by tribe. See, e.g., Jones v. Meehan, 175 U.S. 1, 29 (1899) (determining that right to inherit unrestricted land owned by Indian chief "was controlled by the laws, usages, and customs of the tribe, and not by the law of the state of Minnesota, nor by any action of the Secretary of the Interior"); Bobroff, supra note 77, at 1615; Robert D. Cooter \& Wolfgang Fikentscher, Indian Common Law: The Role of Custom in American Indian Trial Courts, Part II, 46 AM. J. COMP. L. 509, 530-35 (1998) (describing various traditional inheritance patterns).

87. Johnson v. M'Intosh, 21 U.S. 543, 543 (1823); see also LINDSAY G. ROBERTSON, CONQuest by LAW: How the Discovery of America Dispossessed Indigenous Peoples of THEIR LANDS 75-76, 100-12 (2005). 
recognized "right of occupancy" came to be called Indian title. ${ }^{88}$ Although Indians' overall property rights were diminished by the Johnson opinion, the property right at issue in this article - the right to occupy (or use and possess) land-was preserved, remaining nearly absolute unless and until it was terminated in a subsequent transaction endorsed by the federal government. On the remaining Indian land so occupied, tribes continued to allocate use and possession rights to individuals as they saw fit. Indeed, individual Indians' rights to specific tracts post-discovery have been recognized by scholars and courts. ${ }^{89}$

Nearly a century of treaty making followed European contact; through sovereign-to-sovereign treaty instruments, tribal nations sold or traded their occupancy rights to the British and then U.S. government. ${ }^{90}$ The Indian nations reserved to themselves in these transactions certain defined remaining territories (i.e., "reservations") for tribal citizens' exclusive use and enjoyment, and title to these reservation lands went from the limited "Indian title" (i.e., the right of occupancy subject to federal extinguishment only) to a formal "recognized title" that would be subject to Fifth Amendment takings remedies if subsequently taken by the federal government without just compensation. ${ }^{91}$ Originally, within these reserved territories, tribes could continue to apply (or reform based on new circumstances and resource allocations) their internal tenure systems for land use and management. ${ }^{92}$

88. Johnson, 21 U.S. at 543.

89. For example, there were early cases in which railroads did recognize that they should "compensate individual Indians whose fences, cultivated land, and other improvements had been rendered valueless by the railroad" going through traditional Indian lands. Ronald L. Trosper, The Economic Impact of the Allotment Policy on the Flathead Indian Reservation (Aug. 1974) (unpublished Ph.D. dissertation, Harvard University) (on file with the D'Arcy Mcnickle Library, Salish Kootenai College).

Mary and Carrie Dann are another example. However, because the Dann sisters asserted individual property rights outside of recognized tribal territories, it took the Organization of American States to affirm their claims when the federal government would not. See Mary \& Carrie Dann v. United States, Case 11.140, Inter-Am. Comm'n H.R., Report No. 75/02, doc. 5 rev. 1 (Dec. 27, 2002); Comm. for the Elimination of Racial Discrimination, Early Warning and Urgent Action Procedure, Decision 1 (68), United States of America, U.N. Doc. No. CERD/C/USA/DEC/1 (Apr. 11, 2006); see also Allison M. Dussias, Squaw Drudges, Farm Wives, and Dann Sisters' Last Stand: American Indian Women's Resistance to Domestication and the Denial of Their Property Rights, 77 N.C. L. REV. 637 (1999).

90. See generally Felix S. Cohen, Original Indian Title, 32 MinN. L. Rev. 28, 35 (1947); 2012 COHEN HANDBOOK, supra note 8, at 26-29.

91. Compare United States v. Shoshone Tribe of Indians, 304 U.S. 111 (1938) (treaty recognized land is recognized title), with Tee-Hit-Ton Indians v. United States, 348 U.S. 272 (1955) (absent treaty recognition, mere occupancy right of aboriginal Indian title not subject to Fifth Amendment takings liability).

92. E.g., Bobroff, supra note 77, at 1615; Leonard A. Carlson, Learning to Farm: Indian Land 
These original reservation boundaries demarking areas for exclusive Indian use did not, however, remain impenetrable. ${ }^{93}$ Homesteading white farmers and other non-Indian influences grew increasingly anxious at seeing reservation lands that were not producing as they thought necessary. ${ }^{94}$ Demoralized Indian nations increasingly depended on rations from the federal government as they lost their historic tribal survival mechanisms (such as the annual buffalo hunt), and pressure mounted to make the land more productive and the Indians more independent. $^{95}$

\section{Allotment and the Making of Indian Farmers}

In the mid-nineteenth century, the federal government began implementing the federal allotment policy by which reformers sought to establish Western notions of private ownership within Indian Country based on a profound belief in the transformative power of private property. The idea was simple: a formal Western-styled system of private property imposed on individual Indians within the reservation would break up the tribe as a controlling social influence, encourage individualism and self-interest, and promote the progress of autonomous Indian farmers. ${ }^{96}$ These reformers believed that, with the break-up of tribal structures, individual Indians would be driven by "enlightened selfinterest" and "would soon want to accumulate wealth and property [through farming] and... would acquire the habits and customs of Christian society." 97

The idea was that by formalizing individual title to parcels of landrather than allocating individual use rights, if at all, through tribal tenure systems - the federal government could promote more individualistic

Tenure and Farming Before the Dawes Act, in PROPERTY RIGHTS, supra note 10, at 73-74. For a broader history of the reservation era, see generally 2012 COHEN HANDBOOK, supra note 8, at 6064.

93. In addition, reservation boundaries were re-drawn when, for example, the federal government pressured tribes for additional treaty cessions or mandated removal and relocation. See generally id. at 41-51.

94. E.g., Otis, supra note 79, at 432.

95. 2 Francis Paul Prucha, The Great Father: The United States Government and THE AMERICAN INDIANS 661-62 (1984).

96. CARLSON, supra note 1, at 79; see also Bobroff, supra note 77, at 1565; Kathleen R. Guzman, Give or Take an Acre: Property Norms and the Indian Land Consolidation Act, 85 IowA L. REV. 595, 597 n.3 (2000); Royster, supra note 6, at 9.

97. CARLSON, supra note 1 , at 80 . 
behavior by Indians and, in turn, greater exploitation of Indian resources by the Indians themselves. ${ }^{98}$ Thus, through allotment, the federal government imposed a one-size-fits-all version of private property within reservations, erased indigenous tenure systems for allocating individual rights, and formally redistributed reservation lands to individual Indians in parcels ranging on average from 40 to 160 acres in size. ${ }^{99}$ In 1903, the Supreme Court affirmed that the federal government, as an exercise of its plenary power over Indians, could execute these land reforms without Indian consent. ${ }^{100}$

Some of these reformers and allotment advocates did believe that, before allotment, reservation lands were purely owned "in common" and that allotment was introducing private rights in land for the first time. Their contemporaries, however, soon pointed out that the notion of Indian tenure as "communism" was largely inaccurate because "the vast majority of cases of Indian economic pursuits [were] carried on directly with individual rewards in view," including in the Indian agricultural economy specifically. ${ }^{101}$ This was true as much for Pueblo agriculture, which incorporated individualistic farming effort and pooled resources only in the care of the irrigation systems, as it was for the annual buffalo hunt of the Omaha tribe. ${ }^{102}$ By "communism," allotment advocates meant largely that "the title to land invariably vested in the tribe and the actual holding of the land was dependent on its use and occupancy."103

Indeed, even as allotment was being implemented, there were discrete incidents of Indian Office agents recognizing pre-existing tenure systems. For example, in the process of selecting allotments for individual Indians, agents "usually recognized" the claims of any Indians who had already occupied or improved particular tracts of land. ${ }^{104}$ Furthermore, disputes sometimes arose when the federal government deemed certain lands subject to allotment that in fact were subject to prior individual indigenous claims. ${ }^{105}$ For example, on the Pine Ridge reservation in 1904, the allotting agent reported that his allotment

\footnotetext{
98. Otis, supra note 79, at 431.

99. COHEN'S HANDBOOK OF FEDERAL INDIAN LAW § C(2)(d), at 132-34 (Rennard Strickland et al. eds., 1982 ed.) [hereinafter 1982 COHEN HANDBOOK]; see also Royster, supra note 6, at 10-12.

100. See Lone Wolf v. Hitchcock, 187 U.S. 553, 567-68 (1903) (finding Indian consent not required for allotment).

101. Otis, supra note 79 , at 431.

102. Id

103. Id.; see also supra note 79 and accompanying text.

104. Janet A. MCDonnell, Dispossession of the American Indian 7-8, 1887-1934

105. Id. at $22-23$.
} (1991). 
process was being hampered by individuals claiming prior rights to certain desirable land along creeks and by the fact that as many as four families might live on the same section at the time of allotment. ${ }^{106}$ In some instances, the agent worked to convince individuals to agree to arrangements that would allow them to keep their original home and water but then to take the balance of their allotment elsewhere, resulting in the scattering of many families. ${ }^{107}$ Similarly, the Palm Springs reservation agent struggled to implement allotment in 1922 after Indians had been living and farming there peacefully for 36 years. ${ }^{108}$ Individual Indians objected that the allotments would not only separate families but would "disturb the orchards that they had carefully nurtured for years." 109

Nonetheless, allotment did proceed on most reservations, ${ }^{110}$ and on the allotments that were made, individuals were to own their squares of property privately, but not in a straightforward fee simple. Instead, initial allotments were placed in a new, specially designed trust status through which the federal government would act as a trustee overseeing the individual's land management choices for an initial probationary period. ${ }^{111}$

Importantly, this trust status was designed to "protect" individual parcels of land while the Indian allottees completed their intended transformation to farmers. ${ }^{112}$ While a common real estate trust arrangement today might contemplate a trustee taking possession of the trust corpus or res and then managing it directly on behalf of the absentee beneficiary, this initial federal trust protection of Indian lands was designed for an entirely different purpose. ${ }^{113}$ Allotment was intended, instead, to promote Indian enterprise by Indian landowners on Indians'

\footnotetext{
106. Id. at 22 .

107. Id.

108. Id.

109. Id. The policy at Palm Springs at least was ultimately softened so that only Indians who wanted an allotment would receive one, and each Indian was guaranteed a minimum of irrigable acres. $I d$. at 24 .

110. By 1934, 118 of the 213 reservations at that time had been allotted. OFFICE OF INDIAN AfFAirs, U.S. DeP'T OF THE INTERIOR, Indian Land Tenure, Economic Status, and Population Trends, in Supplementary Report of the LAND PlanNing Committee to the NATIONAL RESOURCES BOARD pt. 10, at 5 (1935) [hereinafter 1935 LAND PlANNING].

111. General Allotment (Dawes) Act of 1887, ch. 119, 24 Stat. 388, $\$ 5$ (codified as amended at 25 U.S.C. $\S 348(2012))$.

112. See infra notes $116-20$ and accompanying text.

113. Cf. George T. Bogert, Trusts 352-55 (6th ed. 1987) (describing traditional trustee duties to take possession of the trust res and noting "rare cases" where "the beneficiary is permitted by the trust instrument to have possession of the trust property ....").
} 
own lands. ${ }^{114}$ As Senator Dawes himself articulated, the goal was for an individual Indian to "own the land he cultivates." "While in trust, the allottee had an individual "right of use and enjoyment" in the allotment that would become "absolute ownership" upon the removal of the trust status and conveyance of a fee patent. ${ }^{116}$ An allottee also acquired, by virtue of his allotment, "full possessory rights with respect to the improvements and the timber upon his allotment, as well as the minerals beneath it." 117

The original trust status for allotments did impose a federal restraint on alienation intended to prohibit improvident transfers to Indians or non-Indians while the allottee was becoming "competent" to own and use the land directly without the trust status protections. ${ }^{118}$ In addition, as originally designed, this trust status also denied individual Indian allottees the right to determine, through devise or other tribal inheritance institutions, who received the allotment after death. ${ }^{119}$ Thus, in the period immediately following allotment, the trust status of Indian lands prohibited any transfer of trust title during life or any individual or tribal control of the transfer of the allotment after the allottee's death. ${ }^{120}$ The one thing these allottees did retain, however, was strong use and possession rights. They could use, possess, and exclude others from the allotment as they saw fit, as long as it did not result in a threat to the security of the title (like a mortgage, for example).

114. Otis, supra note 79 , at 430 .

115. Id

116. Felix S. Cohen, Handbook of Federal Indian LaW 220 (1941) [hereinafter 1941 HANDBOOK].

117. 2 T. HaAs, U.S. Indian Service, Tribal Relations Pamphlet No. 3, The Indian \& THE LAW 16 (1949), available at http://horpe.ou.edu/cohen/Indian\%20\&\%20Law\%202 /indian law2.html.

118. See General Allotment (Dawes) Act of 1887, ch. 119, 24 Stat. 388 (codified as amended at 25 U.S.C. $\S \S 331-334,339,341-342,348-349,354,381$ (2012)) (providing for original 25-year trust period); Burke Act of 1906, ch. 2348, 34 Stat. 182 (codified at 25 U.S.C. $§ 349$ (2012)) (authorizing early issuance of a fee (unrestricted) patent to any Indian allottee upon competency determination). Of course, if a given parcel had the trust status removed, then this was fee land that could be sold or otherwise transferred-including to unscrupulous land speculators or through state tax foreclosure sales. See infra Part IV.B.2.

119. Instead of applying traditional tribal inheritance systems, after allotment, all individual allotments necessarily passed by the intestacy laws of the state that surrounded them, often to multiple children and relatives. General Allotment (Dawes) Act of $1887 \S 5$; see also 1982 COHEN HANDBOOK, supra note 99 , at 230-31, § B(4)(a), at 618-19.

120. See United States v. Mitchell, 445 U.S. 535, 544 (1980) (holding allotment's "trust language" was intended to prevent improvident alienation while assuring "immunity from state taxation"). 


\section{B. Unintended Consequences}

Despite allotment's Jeffersonian intentions, the transition from indigenous use-based property systems to federal trust allotments had the perverse effect on the ground of reducing individuals' actual use and occupancy of their own lands. In its implementation, "allotment was followed by a dramatic decline in Indian farming.," "[T]he data . . are remarkably uniform in suggesting that in the years from 1900 to 1930 a clear and widespread pattern of stagnation and decline was evident among the newly allotted Indian farmers." ${ }^{\text {"122 }}$ Part of this experience can be explained by the failure of allotment's administrators to provide sufficient farming supplies and training for the particular types of farming desired, the fact that many allottees received allotments that were too small or too dry for successful farming enterprises, and by the repercussions of the cultural shock that allottees experienced after they were unceremoniously swept into wholesale farming (and isolated living) endeavors. $^{123}$

However, these social, psychological, and physical challenges are not the only causes for the decline in Indian use of Indian land that allotment precipitated. Other significant legal changes also occurred in the period immediately after allotment that indirectly began to erode allottees' rights to make use of reservation land. First, Congress introduced a program to facilitate the leasing of Indian allotments to nonIndians - a program that grew exponentially over time, to the point that today the vast majority of Indian lands that are in use at all are used through a lease arrangement, often to non-Indian lessees. Second, the allotment policy also caused a massive transfer of title to roughly 65 percent of reservation lands from Indians to non-Indians, which further reduced the available land base that new generations of Indian heirs could spread out on and use (and practically compelled more shared ownership arrangements on the land that remained). Finally, the Department of Interior's initial probate program favored sale of allotments after an allottee's death and prohibited wills or tribal

\footnotetext{
121. CARLSON, supra note 1 , at 155.

122. Id. at 155

123. For example, in 1889 , one critic reported the story of "one Indian, with several hundred acres which composed the grants to himself and family, found that he had indeed a vast but unusable possession; a large land estate, but without teams, implements, money, houses or experience, and consequently without power to use a foot of it."' Otis, supra note 79, at 467 (quoting 1889 BD. OF INDIAN COMM'RS ANN. REP. 21, at 105).
} 
inheritance traditions that would have more flexibly consolidated ownership among families.

\section{Introducing the Leasing Program}

The move to BIA-administered leasing of Indian land is perhaps the most fateful step away from Indian use of Indian land. Congress changed the trust restrictions on allotments very early on to permit leasing of allotments while they were still in the trust status. These changes were controversial even at the time because they were directly contrary to the original allotment purpose of converting Indians into land-holding, active, and enterprising farmers themselves. ${ }^{124}$ Leasing converted Indian landowners into passive landlords, not agrarian farmers. ${ }^{125}$ Nonetheless, advocates at the time pushed leasing and emphasized the importance of making the most productive use of land possible, and it was justified by the idea that incorporating some white farmer lessees into the reservation would provide models of Western farming techniques and other civilized behaviors that would help teach the Indian residents self-reliance. ${ }^{126}$ It also, simply, satisfied white settlers' appetite for more land. ${ }^{127}$

The move to leasing began in 1891 when Congress gave the Department of Interior authority to lease the land of allottees who were unable to farm themselves. The leases were limited in type and duration (three years for farming or grazing leases and ten years for mining leases), and the authority extended only to allottees who could not "personally and with benefit to himself occupy or improve" the land "by reason of age or other disability." 128 Over time, the scope of permitted

124. E.g., MCDONNELl, supra note 104, at 46 ("Indian Office officials ... remained torn [because leasing] could also harm the Natives by enabling them to live off rentals rather than farm."). For an additional resource summarizing historical-allotment-related legislation during this period, see Historical Allotment Legislation, INDIAN LAND TENURE Found., www.iltf.org/resources/land-tenure-history/historical-allotment-information (last visited Nov. 20, 2014).

125. MCDONNELL, supra note 104, at 44, 60-70 (describing argument that leasing defeated the purpose of allotment by taking away the allottees' incentives to work and noting concerns about potential fraud and abuse).

126. Id. at 41 .

127. See also Lewis Meriam, The Problem of Indian Administration 476 (Inst. for Gov’t Research ed., 1928) [hereinafter MERIAM REPORT] ("Obviously it is far simpler administratively to lease a good piece of land to a white tenant and to dole the proceeds out to the Indian owner than it is to educate the Indian to work his own land.").

128. Act of Feb. 28, 1891, ch. 383, § 3, 26 Stat. 794, 795 (amending Dawes Act). 
leases dramatically expanded, ${ }^{129}$ and the Department of Interior shifted approval authority from the Secretary to local Indian agents. ${ }^{130}$ These changes had a dramatic effect. Before 1894, the Indian Office approved only 6 or 8 total leases on Indian allotments. ${ }^{131}$ In 1925, over 40,000 leases for grazing and farming were approved on 4 million acres. ${ }^{132}$

\section{Land Loss}

The second major post-allotment development contributing to reduced Indian use of Indian land was significant Indian land loss as a result of allotment-era policies. In addition to a desire to assimilate individual Indians into prototypical Christian farmers who would cultivate their own private lands, allotment was also motivated by a desire to open more land for white farmers' development. ${ }^{133}$ Thus, allotment redistributed significant tracts of Indian land to non-Indians. This occurred primarily in two ways: (1) so-called surplus land sales, and (2) the alienation of individual allotments once fee patents were granted and the initial trust protections removed. As detailed in the following section, early practices related to the descent or devise of allotments after the allottee's death also contributed to this problem.

Most notably, significant swaths of un-allotted Indian lands-the euphemistically entitled "surplus lands"-were often opened by the federal government to white homesteaders and settlers within reservation boundaries. ${ }^{134}$ In total, Indians lost approximately 60 million acres of formerly reserved territories through these surplus land sales, significantly reducing the available remaining land on which future generations could spread out. ${ }^{135}$ As Vine Deloria eloquently described:

The lands were not, of course, surplus. The formula used [for Indian allotments] - 160 acres for the head of the family, eighty acres for older children and wives, and forty acres for minor children, did not look even five years down the road to the future of the tribe. If an adult man were capable of supporting his family on 160 acres, did that mean that

129. E.g., Act of May 31, 1900, ch. 598, 31 Stat. 170 (expanding eligible leasing); Act of June 25,1910 , ch. $431, \S 4,36$ Stat. 856 (codified as amended at 25 U.S.C. $\S 403$ (2012)) (permitting lease for any purpose if Secretary oversaw expenditure of rent income).

130. See 1935 LAND PLANNING, supra note 110, at 7; MCDONNELL, supra note 104, at 49.

131. 1935 LAND PlanNING, supra note 110, at 7; MCDONNELL, supra note 104, at 43.

132. MCDONNELL, supra note 104, at 9-50.

133. Otis, supra note 79 , at $434-35$ ("It is probably true that the most powerful force motivating the allotment policy was the pressure of the land-hungry western settlers.").

134. CARLSON, supra note 1, at 79; see also Royster, supra note 6, at 13-14.

135. MCDONNELL, supra note 104, at 121. 
his eighteen-year-old son could do so on eighty acres, and a decade later his twelve-year-old, now twenty two, on forty acres? ${ }^{136}$

In addition, when an individual allottee was deemed "competent," the trust restrictions on land were removed and he received a straight fee title to the property, this almost always resulted in the ultimate sale of that land to a non-Indian purchaser. ${ }^{137}$ As one government report from 1935 concluded, "[t]he granting of fee patents has been practically synonymous with outright alienation." 138 In total, an additional 23 to 27 million acres of originally allotted Indian land passed out of Indian ownership from these fee patent transactions. ${ }^{139}$ Then, these landless exallottees had no other mechanism for acquiring Indian lands because of the trust status on remaining allotments and the previous sale of "surplus" reservation lands to non-Indians, and therefore in "Indian fashion, the landless and homeless ex-allottees domiciled themselves upon their relatives, thus overpopulating the remaining Indian lands and pressing upon the subsistence which could be wrung from them." 140 "[W]hile the white newcomers steadily consolidated their holdings into good, usable farming and grazing units through their purchases from the allottees, supplemented by leasing, exactly the opposite effect was being worked upon the lands remaining in Indian ownership."141

Putting the surplus land sales and fee patent issues together, a loss of approximately 90 million acres of Indian land (out of 138 million acres of remaining Indian lands at that time) is attributed to the allotment policy. $^{142}$

136. Vine Deloria, Jr., Reserving to Themselves: Treaties and the Powers of Indian Tribes, 38 ARIZ. L. REV. 963, 978 (1996); see also MERIAM REPORT, supra note 127, at 472.

137. 1935 LAND PLANNING, supra note 110, at 6 ("Indians who retained their land after coming into full control over it were rare exceptions.").

138. Id. When the Indian Office took a sample of fee patent results on a group of studied reservations, only 3 to 20 percent of fee-patented land remained in Indian ownership. Id.

139. Id.; see also MCDONNELL, supra note 104, at 88-99 (describing how approximately 27 million acres of lands were lost through "competency determinations" after which newly acquired fee titles were sold or transferred to land speculators who either effectuated the competency determinations in the first place or pounced soon thereafter to acquire land from unsuspecting (and unprotected) allottees).

140. 1935 LAND PLANNING, supra note 110, at 8.

141. Id.

142. Guzman, supra note 96, at 605 (explaining that remaining Native American lands plunged from 138 million acres in 1887 to 48 million acres in 1934, for a total loss of 90 million acres in this time period). 


\section{Mandatory Intestacy and More Land Loss}

Allottees initially had no right to control the disposition of their allotments upon death; Congress did not recognize allottees' rights to devise allotments until $1910{ }^{143}$ Instead of applying traditional tribal inheritance systems to those allotments, which may have been more fluid and able to adapt to the new changing circumstances, all individual allotments passed through the intestacy laws of the state that surrounded them, often to multiple children and relatives without regard to tribal customs or practices. ${ }^{144}$

The Department of Interior also, as a matter of agency practice, sought to liquidate many allotments of deceased allottees through government-supervised sales (with proceeds going to the heirs), or, instead, to pass the allotments to the allottees' heirs in an unprotected fee status without the alienation restrictions of the original trust status (with such fee patents to Indian heirs presumably resulting in alienation to nonIndians at the same high rates as fee patents issued to the original allottees through competency determinations, as described above). ${ }^{145}$ Initially, many of these heirs would have received their own separate allotments already, but this changed over time. ${ }^{146}$ The initial emphasis on liquidation or fee distributions, however, did not change as quickly. ${ }^{147}$

143. Act of June 25,1910 , ch. $431, \S 2,36$ Stat. 855 (codified as amended at 25 U.S.C. $\S 373$ (2012)). This legislation recognized the right of individual Indian allottees who were at least 21 years old to write wills to dispose of allotments that were still held in trust (i.e., before the issuance of the fee patents). To be valid, however, the will had to be "approved by the Commissioner of Indian Affairs and the Secretary of the Interior." Id. At the same time, Congress also permitted an Indian allottee effectively to gift deed (or otherwise "relinquish") the allotment to his or her children who had not themselves received any allotment of land during his or her life. Id.

In 1913, Congress gave this same right to dispose of trust allotments by will to "any persons of the age of twenty-one years having any right, title, or interest in any allotment held under trust"and not just to the original Indian allottee herself. Act of February 14, 1913, ch. 55, § 2, 37 Stat. 678 .

144. General Allotment (Dawes) Act of 1887, ch. 119, 24 Stat. 388 (codified as amended at 25 U.S.C. $\S \S 331-334,339,341-342,348-349,354,381$ (2012)); see also 1982 COHEN HANDBOOK, supra note 99 , at 230-31, 618-19.

145. 1935 LAND PLANNING, supra note 110, at 15-16 (describing government supervised sale of allotment with proceeds distributed to heirs and transfer of allotments to heirs in fee patents as typical actions of the Indian agencies upon an allottee's death); see also MERIAM REPORT, supra note 127 , at 471 .

146. E.g., Deloria, supra note 136, at 978.

147. See, e.g., Act of May 27, 1902, ch. 888, 32 Stat. 245, amended by Act of May 8, 1906, ch. 2348, 34 Stat. 182; Act of May 29, 1908, ch. 216, 35 Stat. 444; Act of June 25, 1910, ch. 431, 36 Stat. 855; Act of Feb. 14, 1913, ch. 55, 37 Stat. 678. 
As time passed, some reforms made the continuation of trust status for heirs plausible. ${ }^{148}$ In 1935, the Office of Interior Affairs reported to Congress that after an allottee died its options and common practices were to (1) sell the allotment, (2) issue a fee patent to the heirs as coowners, (3) physically partition the allotment with heirs receiving individual patents to a portion of the former allotment in either fee or trust, depending on the competency of the individual heir (thus avoiding any co-ownership issues), or (4) maintain the trust status of the allotment but have the superintendent lease the land "for the benefit of the heirs" (apparently instead of the heirs themselves making any direct use of it). ${ }^{149}$

Notably, these practices favored fee patents and outright sales. There was no support or even a clear mechanism for new co-owners to consolidate interests fairly and efficiently or to support shared ownership arrangements among heirs or devisees within the preserved trust status. ${ }^{150}$ Thus, while the practice of white farmers at the time had been to devise their farms and improvements to a single heir, who then took out a loan secured by a mortgage to pay the other heirs in cash, this was not possible in the context of Indian lands-first because of the initial prohibition on wills and then because of the alienation (and therefore mortgaging) restrictions. ${ }^{151}$ Instead, the rules governing the distributions of allotments upon the death of the allottee that were in place immediately after allotment further separated Indian landowners from the use of their own land.

\section{Fractionation and a Permanent Trust Status}

Thus, even as allotment intended to promote private landownership and Indian landowners' cultivation of their own lands, the experience on the ground was exactly the opposite. By the 1920s, leasing of Indian land to non-Indians had dramatically expanded, and more than 65 percent of the Indian land base had been sold to non-Indians. ${ }^{152}$ Allotment had decreased the flexibility of Indian owners to use their own

148. E.g., Act of May 18, 1916, ch. 125, §1, 39 Stat. 127 (authorizing a partition in kind upon an allottee's death with fee patents issued to competent heirs and trust patents to the incompetent heirs).

149. 1935 LAND PLANNING, supra note 110, at 15-16.

150. In 1934, Congress found that allottees' heirs were making appreciable use of Indian land on only two of sixteen studied reservations. $I d$. at 20.

151. Id. at 2 .

152. Documents of United States Indian Policy 219-21 (Francis Paul Prucha ed., 2d ed. 1990) (summarizing MERIAM REPORT, supra note 127). 
land and increased bureaucratic burdens. A 1928 Congressional study of Indian farming found that, after allotment, "the number of real farmers is comparatively small" and the majority of Indians "are considerably below any satisfactory standard for subsistence farming." 153 This report blamed federal policy "allowing or even encouraging Indians to lease or sell their lands and live off the proceeds." ${ }^{154}$ A year earlier, a similar federal study - this time of irrigated farming on Indian reservationsfound that " 32 percent of the irrigated lands on Indian reservations... was farmed by Indians, with 68 percent ... farmed by white owners (37 percent) or white lessors (31 percent). ${ }^{, 155}$ Moreover, this report warned "the acreage utilized by Indians is continuously decreasing, while the acreage utilized by whites is increasing."156

As skepticism about allotment's actual effects grew, Congress passed the Indian Reorganization Act (IRA) in 1934 in part to reverse the growing pattern of non-Indian use and ownership of Indian lands and to encourage "home rule" by Indians. ${ }^{157}$ By 1938, the official handbook of federal Indian policy prepared by the Office of Indian Affairs provided that "Indian land policy definitely looks toward the substitution of Indian use for non-Indian use of Indian lands." 158 As the Department of Interior explained in 1945, "[t]he primary object of Indian land policy is to save and to provide for the Indian people adequate land, in such a tenure and in accordance with such proper usage that they may subsist on it permanently by their own labor."

The IRA formally put an end to the allotment policy and prohibited further subdivision of reservation lands to individual Indians in severalty. ${ }^{160}$ The IRA also extended the trust status of remaining allotments and its accompanying restrictions on alienation and

153. CARLSON, supra note 1 , at 134 .

154. Id. at 135

155. Id. (citing Review of Conditions of the Indians in the United States: Hearings Before the Commission on Indian Affairs, 71st Cong. 308, 2210-2661 (1930)).

156. Id.

157. See generally Wheeler-Howard Act, ch. 576, 48 Stat. 984 (1934) (codified as amended at 25 U.S.C. $\S \S 461-494$ (2012)).

158. 1941 HANDBOOK, supra note 116, at 235 n.176 (quoting OFFICE OF INDIAN AFFAIRS, U.S. DEP'T OF THE INTERIOR, HANDBOOK OF INDIAN LAND POLICY AND MANUAL OF PROCEDURES, at $1-$ 3 (1938); see also MERIAM REPORT, supra note 127, at 469 ("The primary duty [of the Indian Service] is to educate the Indians in the use and management of their own property.").

159. 1941 HANDBOOK, supra note 116, at 235 n.176 (quoting OFFICE OF INDIAN AFFAIRS, U.S. DEP'T OF THE INTERIOR, HANDBOOK OF INDIAN LAND POLICY AND MANUAL OF PROCEDURES, at 13 (1938)).

160. Wheeler-Howard Act $\S 1$. 
bureaucratic oversight indefinitely (a status that remains today). ${ }^{161}$ As with its stated purpose during allotment, this now-permanent trust status was intended to preserve title in Indian hands while Indians made use of their own land as owners. ${ }^{162}$ The IRA also directed the Department of Interior to promulgate "such other rules and regulations as may be necessary ... to assure full utilization of the range, and like purposes."163

Although intended as a fix, the IRA exchanged one set of land tenure problems (allotment and land loss) for another (permanent restrictive trust title and expanding federal bureaucracy). Very quickly, as liquidation of allotments or forced-issuing of fee patents no longer occurred, the fractionation problem expanded. ${ }^{164}$ By the 1930s, 6.25 million acres, or 35 percent of remaining allotments, were co-owned in trust by multiple heirs, ${ }^{165}$ and critics of the IRA's permanent trust status described further fractionation of these titles among increasing numbers of co-owners as "a definite certainty" given the permanent transfer restrictions and bureaucracy imposed by the IRA. ${ }^{166}$ By the 1960 s, half of allotments were in heirship status. ${ }^{167}$ This would prove important because, although the IRA was intended to reaffirm the importance of Indian use of Indian lands, the increasingly fractionated condition of the Indian land base would ultimately be used to justify further limits on those co-owner's retained property rights.

\footnotetext{
161. Wheeler-Howard Act $\S 2$; see also 1935 LAND PLANNING, supra note 110, at 4.

162. See supra notes $116-20,157-59$ and accompanying text.

163. Wheeler-Howard Act $\S 6$.

164. H. COMM. ON INTERIOR AND INSUlar AFFAIRS, 86TH CONG., INDIAN HEIRSHIP LAND STUdy: ANALYSIS OF INDIAN OPINION AS EXPRESSED IN QUESTIONNAIRES, xiii (Comm. Print 27) (Dec. 31, 1960) [hereinafter HEIRSHIP STUDY] (describing fractionation as "one of the most serious problems facing our American Indian population"); 1935 LAND PLANNING, supra note 110, at 3; 1941 HANDBOOK, supra note 116, at 234-35 (concluding "[t]hese heirship tracts are potentially one of the most important of the Indian resources" and describing "what to do with these lands ... [as] of paramount importance").

165. 1935 LAND PLANNING, supra note 110, at 5, 15.

166. 1941 HANDBOOK, supra note 116, at 234.

167. William H. Gilbert \& John L. Taylor, Indian Land Questions, 8 ARIZ. L. REV. 102, 107-08, 110 (1966) (analyzing Congressional reports on Indian land issues from 1952 to 1965); see also Ethel Williams, Too Little Land, Too Many Heirs-The Indian Heirship Land Problem, 46 WASH. L. REV. 709, 713 (1971) (noting that more than a dozen bills had been introduced in Congress between the Meriam Report and 1971 but none had been enacted and analyzing some related Congressional reports); Wesley L. Nutten, III, Probate Problems of the American Indian, 7 REAL ProP. PROB. \& TR. J. 495, 500 (1972) (describing how "continual fractionation of allotted lands presents a serious problem which has hampered realistic and economic use of Indian lands").
} 


\section{The Persistence of Some Owner's Use}

After the IRA halted allotment, new rounds of Congressional legislation reflected continued support for Indian users and possessors of Indian lands, even while simultaneously making it easier to lease those lands to third parties. The logic was to prioritize and carve out protections for an owner's use and possession of her own land, where it was occurring, but to facilitate third-party leasing where it was not.

\section{Preemptive Power}

While the IRA ultimately exacerbated fractionation as a practical matter, it made no direct legal changes to the retained possession rights of individual co-owners. Because the original allottee had full possession rights, presumably his heirs, and their heirs after that, inherited those same rights, albeit in a shared ownership form. ${ }^{168}$ Congress did not explicitly define the co-ownership rules to govern the relationships among these heirs as co-owners, and at least in theory this should have been the province of the governing tribe. However, perhaps the federal government's most direct post-IRA statement on the issue came in a leasing act passed in 1940. This 1940 statute, which remains in effect today, defines the conditions under which reservation superintendents (agency-level BIA employees) may execute surface leases of allotments on behalf of an allotment's owners - that is, when the Secretary can grant leases of Indian lands without the owners' consent, as opposed to when the Secretary can approve leases otherwise agreed to by the co-owners themselves. ${ }^{169}$ The statute applies to allotments only after the original allottee has died, and it provides that a reservation superintendent can grant a lease of an allotment without the co-owners' consent: (1) while the allotment is still in the process of being probated, or (2) when the new generations of co-owners cannot reach their own lease agreement in a three-month period-as long as the "lands

168. See supra note 34 and accompanying text.

169. Act of July 8, 1940, Pub. L. No. 76-732, 54 Stat. 745 (codified as amended at 25 U.S.C. $\S$ 380 (2012)). While the 1940 Act authorized the superintendents to execute leases on the landowners' behalf (i.e., without landowner consent), other preceding and subsequent legislation clarified that landowners could still themselves agree to a lease of their own land, if the BIA approved it. E.g., Indian Long-Term Leasing Act, ch. 615, 69 Stat. 539 (1955) (codified as amended at 25 U.S.C. $\S \S 415,415$ (a) (2012)); see also Goodluck-Jones v. Navajo Reg'l Dir., Bureau of Indian Affairs, 56 I.B.I.A. 257 (2013) (discussing modern difference between BIA approval and BIA granting authorities in leasing); Robert McCarthy, The Bureau of Indian Affairs and the Federal Trust Obligation to American Indians, 19 BYU J. PUB. L. 1 (2004). 
are not in use by any of the heirs" at that time. ${ }^{170}$ This legislation is codified at 25 U.S.C. $\S 380$, and it will hereinafter be referred to as the "1940 Act."

On the one hand, this 1940 Act greatly facilitated the leasing of allotted Indian land to non-owners (predominately non-Indians) by expanding the superintendents' authority to lease allotments on behalf of Indian owners, even without the owners' consent. Indeed, this was the primary purpose for which Acting Secretary of Interior E.K. Burlew first requested Congress to pass this legislation. ${ }^{171}$ In his communication to the Speaker of the House submitting his request for this legislation, Secretary Burlew noted that leasing is the "only method in many cases of deriving some benefit from the land" as it was "often not possible for all of the heirs or devisees, or even a majority of them, to agree upon the use to be made of the land." 172 He explained that as the numbers of coowners increased, heirs or devisees were frequently unable to agree about who should lease the land or at what price. In some cases, individuals' interests were so small that the owners would simply refuse to agree to a lease "because of the small intrinsic value of their interest in the land."173 Thus, Secretary Burlew sought a more simplified leasing program that would allow superintendents to execute leases "whenever such lands are not in use by any of such Indians and they have not been able during a 3-month period to agree upon a lease" in order to "protect[] the land and its value, [e]nsure an income to the interested Indians and reduce the cost to the Government in administering such lands."174

At this point in history, as Secretary Burlew's comments may imply, the Department of Interior seemed to require as a matter of practice unanimous co-owner consent before an owner-negotiated lease to a third party could be considered for BIA approval. ${ }^{175}$ This high standard of

\footnotetext{
170. Act of July 8, 1940, 54 Stat. 745 .

171. See S. ReP. NO. 76-1570 (1940); H.R. REP. NO. 76-1615 (1940).

172. Id. (reprinting communication dated January 16, 1940).

173. S. REP. NO. 76-1570.

174. Id.

175. See, e.g., HeIRSHIP STUDY, supra note 164, at 3. The source of this 100-percent approval interpretation is not entirely clear, but more recently, the Senate Indian Affairs Committee reported that the Department of Interior's historic understanding that unanimous co-owner consent was required before there could be "a lease, agreement, or the sale of natural resources associated with allotted lands" may have been an "implication" from nineteenth and early twentieth century statutes that "refer to the lease or use of these lands upon the approval of "the owner," which at least raised "the question of whether this requires the approval of each undivided interest holder, even when these individuals number in the thousands." S. REP. No. 106-361, at 22-23 (2000). Likewise, thenAssistant Secretary for Indian Affairs Kevin Gover testified in 1999 that the Department of Interior interpreted the mineral leasing statute at 25 U.S.C. $§ 396$ to "require[] that the consent of all the
} 
perfect co-owner unanimity to a lease is inapposite to the renting options available in non-Indian jurisdictions where any individual co-owner may typically lease her undivided interest as long as she shares the resulting rental income with her other co-owners proportionately. Further, other remedies such as ouster and partition exist in those jurisdictions to resolve conflicts among lessees and other active co-owners, without the need to make unanimous consent a prerequisite to every third party lease. ${ }^{176}$

Requiring complete co-owner agreement before any Indian lease could be approved would have made leasing to third parties more difficult, as Secretary Burlew complained; however, it may also have had indirect advantages for co-owners' own possession rights in the Indian context. With a 100 percent approval rule for owner-negotiated leases, a single Indian co-owner in actual possession of the property would have essentially been able to veto any owner-negotiated lease to a different party, simply by refusing to consent to the lease pursued by the other coowners themselves (and thus precluding them from reaching the necessary unanimity of consent to the proposed lease).

The 1940 Act did not address or change the Department of Interior's interpretation of this 100 percent rule itself; instead, it provided new authority for the Department to grant its own lease of the land (without any co-owner consent at all) if the owners could not all agree to a lease on their own and as long as one of the co-owners was not using the land already. ${ }^{177}$ In this way, both the 1940 Act and Secretary Burlew's

owners of a tract of trust... land be obtained prior to the approval of a mineral lease by the Secretary of the Interior" and argued that, due to fractionation, this 100 percent consent requirement precluded full Indian participation in mineral exploration and development. Indian Land Consolidation Act Amendments; and to Permit the Leasing of Oil and Gas on Navajo Allotted Lands: Joint Hearing on S. 1586 and S. 1315, H.R. 3181 Before the S. Comm. On Indian Affairs and the H. Comm. on Resources, 106th Cong. 47-54 (1999) (statement of Kevin Gover, Assistant Sec'y for Indian Affairs). The statute cited by the then-Assistant Secretary Gover, however, says only that "[a]ll lands allotted to Indians in severalty . . . may by said allottee by leased for mining purposes" if the Secretary deems it advisable. Act of March 3, 1909, ch. 263, 35 Stat. 783 (codified as amended at 25 U.S.C. $\S 396$ (2012)). Nothing in the statute itself expressly requires unanimous co-owner consent where the original "allottee" has died or otherwise transferred ownership. Nonetheless, until subsequent legislative changes to the leasing consent requirements, this seems to have been the Department of Interior's fairly consistent position. Cf. infra note 196 (discussing modern 50 percent rule for agricultural leases) and notes 232-34 (discussing modern sliding scale consent rules for other leases) and accompanying text.

176. See supra Part II.

177. Although the 1940 Act speaks only of "heirs" in direct use of the allotment as precluding a third-party lease, the Department has consistently interpreted this as protecting both "heirs and devisees" who own an interest in the allotment. For example, when the first significant Indian 
comments implicitly recognized and protected some pre-existing rights of Indian co-owners to use and possess their jointly owned land. Under the 1940 Act, the Secretary could avoid the consent challenges of the 100 percent rule, but only if such "lands are not in use by any of the heirs" themselves. ${ }^{178}$

In combination, the 1940 Act's prohibition on the Department of Interior's leasing where a co-owner was already using the land, and the 100 percent approval rule for owner-negotiated leases, gave strong protections to a co-owner's use rights. A single co-owner in actual possession of the property could have prevented any third-party leasing - either by holding out from the other owners' attempts to get 100 percent agreement on an owner-negotiated lease or by directly preempting the authority of the BIA to execute a lease to another lessee on the owners' behalf under the 1940 Act. Beyond this basic framework, however, neither the 1940 Act nor any identified Department of Interior regulations defined precisely the parameters of these pre-existing rights of co-owners. Instead, the Interior Board of Indian Appeals (IBIA) did much of the work of setting out the scope of this protected owner's use right through the end of the twentieth century. ${ }^{179}$

\section{Agency Interpretations}

One of the most important threshold issues left open to interpretation was what constituted "in use" for purposes of the 1940 Act's carve out of the BIA's authority to lease the land. What exactly was the scope of the co-owner's use rights implied by this preemption? Nothing in the 1940 Act's language conditioned the heir's qualifying "use" on any prior coowner or BIA permission in any way, and no such consent would be required in a traditional tenancy in common framework. However, at least some historical references suggest there may have been some

leasing regulations were published in the Code of Federal Regulations in 1961, the Department of Interior's regulations affirmed that the Secretary could grant leases of allotments on behalf of allotment co-owners who had not been able to agree to their own lease in a three-month prior period but only "provided, that the land is not in use by any of the heirs or devisees." 25 C.F.R. $\S 131.2$ (1961) (recodifed at 25 C.F.R. § 162.2(a)(4) (1982)) (emphasis added) ("Grants of leases by Secretary").

178. Act of July 8, 1940, 54 Stat. 745.

179. The IBIA hears various administrative appeals on behalf of the Secretary of Interior, including leasing and land-related appeals from decisions by the BIA. See generally The Board's Jurisdiction in General, U.S. DEP'T OF THE INTERIOR, http://www.doi.gov/oha/ibia/the-boardjurisdiction-in-general.cfm (last visited Nov. 24, 2014). 
confusion or uncertainty about whether, essentially, the Department of Interior should expand, in practice, the "100 percent consent" concept to an owner's own possession as well-assuming that a co-owner too needed unanimous permission from his co-owners before putting her own land to her own use. ${ }^{180}$

Although not always consistent, the IBIA did correctly confirm in at least some cases that a co-owner of Indian land had the right to put her own land "in use" informally, directly, and without any prior permission from other co-owners or the BIA. This kind of informally initiated owner's use precluded the BIA or the other owners from leasing the land out to someone else. ${ }^{181}$ This understanding of the informality and directness of the Indian owner's use rights is also consistent with the language and logic of the 1940 Act. If the owner's use rights referred to in the 1940 Act had to be pursuant to a formal lease or other agreement from the other co-owners in order to be valid, this language preempting BIA leasing in the 1940 Act would be superfluous. It would mean that the agency could not grant a new lease for an allotment when a co-owner of the allotment was already leasing the land from her co-owners, but of

180. E.g., HeIRSHIP STUdY, supra note 164, at 7 (noting that although many Indian heirs reported intention to use heirship land in the future "[a] question arises here as to whether these heirs [who] intended to use heirship land in the future are aware that permission is needed from the other heirs and that this (according to the heir's [sic] statements in the returns) is very difficult to obtain"). On this theme, it is also important to stress that historically there has often been significant variance among the Department of Interior and BIA offices, especially at the reservation agency level, as to how specific real estate issues were addressed (especially in the absence of clear regulatory and statutory guidance). E.g., U.S. Gov'T ACCOUNTABILITY OFFICE, GAO/AIMD-00-259, INDIAN TRUST FundS: IMPROVEMENTS MADE IN ACQUiSITION OF NEW AsSET AND ACCOUNTING System But SigNificANT Risks REMAIN 18 (2006). This local variance likely also existed in some instances about the scope of owner's use rights until recently. E.g., Blackhawk v. Billings Area Dir., Bureau of Indian Affairs, 24 I.B.I.A. 275, 281 \& n.7 (1993) (discussing example of same); infra notes 288-91 and accompanying text.

181. Lower Peoples Creek Coop. v. Acting Billings Area Dir., Bureau of Indian Affairs, 23 I.B.I.A. 297, 301, 303-04 (1993) (holding that agency superintendent did not have authority to lease out a portion of a jointly owned allotment that was already being informally used as a homesite by a co-owner even where that co-owner's ongoing use was possibly without the consent of the other coowners; also noting that informal co-owner use arrangements like this, without any kind of formal lease, were common at this time); see also Blackhawk, 24 I.B.I.A. at 281-82 \& n.7 (explaining that the owners' use rights protected in the 1940 Act "apply only in a case where the land is already in use by one of the landowners," including in at least some cases landowners who initiate use "without entering into any agreement with his co-owners"; also holding that special tribal or agency-level owners' use policies must reflect at least some respect for these threshold owners' use rights); Whiteman v. Billings Area Dir., Bureau of Indian Affairs, 25 I.B.I.A. 292, 293, 295 (1994) (quoting BIA statement that co-owner has right to "make use of his own land" as long as "the property is currently in use by the person claiming owner's use" and holding that it was only because co-owner had not supported his allegation of pre-existing use of the allotment that the BIA could advertise a lease to another party instead). 
course, even without the 1940 Act, the BIA could never grant a new lease when a current lease was already effect. ${ }^{182}$

In 1996, the Department of Interior in regulatory comments also acknowledged that the 1940 Act 'allowed the 'heirs and devisees' of allottees to prevent us from exercising our broad grant authority on heirship land, by putting the land to direct use." ${ }^{, 83}$ In this way, at least some co-owners of Indian lands did enjoy the preemptive right to put "the land to direct use" similar to the rights of non-Indian co-tenants, and this Indian owner's use right also worked affirmatively to preclude the Department from leasing the land to another party. ${ }^{184}$

Although acknowledging the continued validity of these owner's use rights in general, the IBIA did institute some other limits on such claims. ${ }^{185}$ For example, the IBIA came to require that the owner claiming an owner's use right had to prove historic, continuous, and current use of the property in order to assert protection from a current request to lease the land to another, and an owner could only claim this preemptive owner's use right over the portion of the allotment that she was actively putting "in use," not necessarily or automatically the entire legal tract. ${ }^{186}$ The IBIA also prohibited an owner from sub-leasing or assigning her owner's use rights to a non-owner. ${ }^{187}$

In addition, the IBIA limited the owner's use protections under the 1940 Act to "heirs or devisees" and did not extend protections to other co-owners who acquired interests in the allotment by purchase or other

182. See also Blackhawk, 24 I.B.I.A. at 281-82 (requiring that any special or more onerous tribal owner's use policies be read in conjunction with this protection of owner's use rights in the 1940 Act).

183. Leasing and Permitting, 61 Fed. Reg. 30560-01, 30562-63 (proposed June 17, 1996) (revising 25 C.F.R. pt. 162).

184. Id. at 30563; see also Bobroff, supra note 77, at 1617 (explaining that "there is little doubt that co-owners then [in 1892], as they do today [in 2001], reached accommodations allowing some uses of the land").

185. Blackhawk, 24 I.B.I.A. at 280-81 (recognizing some owner's use practices); Danks v. Aberdeen Area Dir., Bureau of Indian Affairs, 20 I.B.I.A. 79, 80 (1991) (noting that owner of 13/63 interest in allotment "evidently farm[s] all or part... under some kind of 'owner's use' arrangement"); Smith v. Acting Anadarko Area Dir., Bureau of Indian Affairs, 34 I.B.I.A. 283, 286 \& n.5 (2000) (lamenting "lack of regulatory guidance" and some continuing uncertainty about "situations where an allotment is in fractionated ownership and one co-owner invokes 'owner's use' of all or part of the allotment").

186. Whiteman, 25 I.B.I.A. at 295 (requiring proof of actual owner's use); Evans v. Sacramento Area Dir., Bureau of Indian Affairs, 28 I.B.I.A. 124 (1995) (no analysis of owner's use rights where co-owner's prior house on allotment had burned down several years ago and thus she had apparently not maintained any kind of continuous use); Emm v. Phx. Area Dir., Bureau of Indian Affairs (Emm II), 34 I.B.I.A. 260, 263-64 (2000) (limiting use claim to area actually used); Lower Peoples Creek Coop., 23 I.B.I.A. at 303-04 (same).

187. Smith, 34 I.B.I.A. at $286-87$. 
means. ${ }^{188}$ The IBIA noted that excluding purchasers in this way would "prevent[], for example, an individual from purchasing a small interest in heirship land and filing for Owner's Use on the entire tract." 189 This also, of course, would have further reduced any market value of these small interests as, apparently, a purchaser could not buy all the same direct use and possession rights that her co-owners could inherit.

\section{Modeling Indian Farmers, Again}

Meanwhile, in 1993, Congress again became concerned with a decline in federal support for Indians' agricultural endeavors on Indian lands and the fact that significant acres of Indian agricultural land were idle. ${ }^{190}$ In response, Congress passed the American Indian Agricultural Resource Management Act (AIARMA), ${ }^{191}$ which applies to "agricultural land" in Indian Country. ${ }^{192}$ AIARMA is essentially a federal land use statute for Indian agricultural lands. Two of AIARMA's stated purposes are to affirm the role of tribal governments in the management and regulation of Indian agricultural lands and "to enhance the capability of Indian ranchers and farmers to produce crops and products from such lands." 193 In particular, AIARMA requires that Indian agricultural lands be managed " $[\mathrm{t}] \mathrm{o}$ enable Indian farmers and ranchers to maximize the potential benefits available to them through their land." 194 Further, to the extent AIARMA authorizes the Secretary to assist in Indian land management, the Secretary's involvement is to be "with the participation of the beneficial owners of the land, in a manner consistent with ... the objectives of the beneficial owners." 195

188. Fenner v. Acting Billings Area Dir., Bureau of Indian Affairs, 29 I.B.I.A. 116, 119-20 (1996).

189. Id. at 119 n.7; see also Blackhawk, 24 I.B.I.A. at 279 n.3.

190. See S. REP. No. 103-186, at 1 (1993), reprinted in 1993 U.S.C.C.A.N. 2459, 2460 (noting "over 1.1 million acres of Indian trust land lay idle nationwide").

191. Pub. L. No. 103-177, tit. I, § 105, 107 Stat. 2011, 2017-18 (1993); see also Pub. L. No. 103-435, § 12(a), 108 Stat. 4566, 4572 (1994) (technical amendments).

192. 25 U.S.C. $\$ 3703(1)(2012)$.

193. S. REP. NO. 103-186, at 1 (analyzing H.R. 1425). AIARMA's findings and purposes are also codified at 25 U.S.C. $\$ \S 3701-3702$. The congressional findings, in particular, note that "Indian agricultural lands ... are vital to the economic, social, and cultural welfare of many Indian tribes and their members" and planned development and management of these lands "will produce increased economic returns, enhance Indian self-determination, promote employment opportunities, and improve the social and economic well-being of Indian and surrounding communities." 25 U.S.C. § 3701(3)-(4).

194. 25 U.S.C. $\$ 3711(4)$.

195. 25 U.S.C. $\$ 3702(2)$. 
Thus, with AIARMA - as with allotment, the IRA, and arguably the 1940 Act before it - Congress yet again articulated a policy of promoting Indian autonomy on Indian land. One of the most significant changes of AIARMA was to permit only a majority of the individual owners of Indian agricultural land to enter into an agricultural lease of that land, ${ }^{196}$ instead of the 100 percent consent requirement prior to AIARMA. ${ }^{197}$ Thus, theoretically under AIARMA, a smaller group of owners - a bare majority of trust interests - could bind non-consenting co-owners to an agricultural lease of the land. ${ }^{198}$ If limited to this plain language alone, this majority-consent rule for third-party agricultural leases could have been read to permit co-owners to lease without regard to the interests of a minority-interest owner who was currently in informally initiated possession of the land. Whereas a single owner in possession had an implicit right to veto a lease to a third party under the former 100-percent consent rule, the new AIARMA rule may have been interpreted to mean that 51 percent of the trust interests in the land could lease 100 percent of the land over the objection of even a 49 percent co-owner in current use and possession of any portion of the land.

Despite (or perhaps because of) this apparent conflict, AIARMA also provided under related statutory language entitled "Rights of individual landowners":

Nothing in this section shall be construed as limiting or altering the authority or right of an individual allottee or Indian tribe in the legal or beneficial use of his, her, or its own land or to enter into an agricultural lease of the surface interest of his, her, or its allotment or land under any other provision of law.

At least initially, the IBIA interpreted this language as providing significantly expanded protections of owner's use rights in agricultural land, even beyond what was protected by the 1940 Act.

In 1996, the IBIA heard an important case involving an agricultural lease on the Walker Indian Reservation involving an in-tenant named Roger Williams. Williams purchased a one-third interest in the allotment and had, 15 years earlier, erected a fence around approximately six acres of the lot, roughly equivalent to one-third of the acreage in the

\footnotetext{
196. 25 U.S.C. $\$ 3715(\mathrm{c})(2)(\mathrm{A})$.

197. See, e.g., supra note 175 and accompanying text.

198. 25 U.S.C. $\S 3715(c)(2)(A) ; 25$ C.F.R. $\S \S 162.207(c), 162.209$ (2006). Ultimately, this leasing percentage requirement was modified for non-agricultural leases, too. See infra notes 232-34 and accompanying text.

199. 25 U.S.C. $\S 3715(\mathrm{c})(1)$.
} 
allotment. ${ }^{200}$ When the other co-owners of the allotment sought to lease the land to someone else, Williams claimed owner's use rights under AIARMA to that portion of the allotment that he had been farming for 15 years. ${ }^{201}$ Despite objections by some of the other co-owners, the IBIA ultimately concluded that the agency could not lease the portion of the allotment that Williams was using to anyone else, even where a majority of the other ownership interests in the property would have consented to do so. ${ }^{202}$ Thus, Williams could preclude a majority of co-owners from otherwise exercising their rights under AIARMA to lease the land out from under him because it interfered with his pre-existing owner's use rights, which the IBIA read AIARMA to protect, regardless of how Williams came into ownership of his trust interest. ${ }^{203}$

In reaching this decision, the IBIA acknowledged that the term "allottee" used in the "rights of individual landowners" section of the statute "is a term of art in Indian law," and could be read to mean only "the individual to whom an allotment of land was made" had his preexisting owner's use rights preserved and protected under AIARMA. ${ }^{204}$ The Board reasoned, however, that because no allotments had been made since 1934 "only a small percentage of trust or restricted land [was] still owned by 'allottees" in $1996 .{ }^{205}$ In any event "each 'allottee' normally owns the full interest in the allotment he or she received" so the protections from BIA for co-owner leasing would not be required. ${ }^{206}$ Moreover, the IBIA emphasized that the purpose of AIARMA was to "enhance the capability of Indian ranchers and farmers to produce crops" from Indian lands, ${ }^{207}$ regardless of how they came to own the land at issue. ${ }^{208}$ Thus, the IBIA reasoned that Congress did not intend for Indian

200. Emm v. Phx. Area Dir., Bureau of Indian Affairs (Emm I), 30 I.B.I.A. 72, $72-74$ (1996).

201. Id. Williams alleged that he had been farming this fenced-in portion of the allotment for 15 years, that one of the other co-owners had helped him set the corner posts for the fence, and that he needed the hay produced on "his" portion of the allotment for his cattle. Id. at 73-74.

202. Id. at 74,81 . The Board subsequently clarified its decision in 2000 to hold that only the portion of the allotment that Williams was using was subject to his owner's use rights, and the BIA only needed to remove that portion of the allotment - not the entire allotment - from the appealed lease. Emm II, 34 I.B.I.A. 260, 263-64 (2000).

203. As described in more detail in the following section, by this time, the IBIA was already requiring in-tenants in possession to pay their co-owners for their use of their land, and so Williams was required to "compensate the other co-owners." Emm I, 30 I.B.I.A. at 81 n.11 (citing Lower Peoples Creek Coop. v. Acting Billings Area Dir., Bureau of Indian Affairs, 23 I.B.I.A. 297 (1993)).

204. Id. at 76.

205. Id.

206. Id.

207. Id. at 78 (quoting S. REP. No. 103-186, at 1 (1993), reprinted in 1993 U.S.C.C.A.N. 2459).

208. Id. at 79 ("[T] he Board finds nothing in the legislative history which suggests Congress believed Indian landowners should be treated differently based upon the way in which they acquired 
landowners to be treated differently based on how they acquired their interest in trust land and, implicitly, that Congress intended to promote Indian use of Indian land with a strong protection for individuals' preexisting property rights to use and possess even their jointly owned agricultural land. ${ }^{209}$

\section{Requiring Rent}

Finally, the IBIA also came to require-without much discussion or any reference to a specific statutory mandate-that a co-owner in possession of his or her own land pay reasonable rent to her co-owners in exchange for her use and possession of their jointly owned land, although this was not always consistently applied in practice. ${ }^{210}$ In contrast, traditional tenancy in common rules do not require an in-tenant to compensate her co-owners for exercising her own possession rights in this way unless there has been an ouster, and ouster requires an actual conflict between two active owners. ${ }^{211}$

According to the IBIA, unlike in a traditional tenancy in common, an Indian co-owner's "right to receive compensation for [another coowner's] use of their interests in the allotment" vests regardless of

their interest in trust or restricted land."); see also DEP'T OF THE INTERIOR, PROCEDURAL HANDBOOK: LEASING AND PERMITTING 11 (2006) [hereinafter 2006 LEASING HANDBOOK] (copy on file with author) (requiring, after subsequent 2001 rule changes, a lease or unanimous co-owner permission for "Indian landowners," without mention of method of interest acquisition).

209. Emm I, 30 I.B.I.A. at 78-80.

210. Lower Peoples Creek Coop. v. Acting Billings Area, Dir., Bureau of Indian Affairs, 23 I.B.I.A. 297, $304 \&$ n.10. (1993). The conflict in Lower Peoples Creek was between a co-owner in possession and a "cooperative of landowners" who were seeking a lease of the same property. Id. at 298. The cooperative itself was not a co-owner, but the fact that some of the cooperative's individual members may have been co-owners may have provided a way of reconciling that case with the traditional no-rent rule for co-owners in possession (because it looked more like a traditional ouster dispute between co-owners here).

It is also important to note, however, that because many decisions on co-owner use are made at the agency level, it is difficult to pinpoint precisely if the BIA may have begun requiring coowner rental payments before this date, at least in some places. See supra note 180 (also discussing real estate practice variances among BIA offices). The Department of Interior did include this rent requirement in its internal Procedural Handbook in 2006. See 2006 LEASING HANDBOOK, supra note 208, at 11 (providing that while an Indian landowner using his or her own land "must pay his coowners at least fair market rental unless those co-owners have waived their right to receive rental income"). However, as some commentators established in response to the Department of Interior's new leasing regulations expressly requiring rent payments in most cases, this prior IBIA requirement was not always applied consistently at every agency and in every case. See infra notes 288-91 and accompanying text.

211. See supra notes $42-45$ and accompanying text. 
whether that co-owner has ever tried to use or been denied access to the property. ${ }^{212}$ Instead, according to the IBIA, "[i]t is [the occupying coowner's] personal, long-term occupancy or 'possession' of the landwhich he does not dispute - that gives rise to Appellant's obligation to pay rent to his co-owners." 213

In another opinion, the IBIA also cited with apparent approval a BIA letter that suggested that a co-owner in possession not only owed rent for her actual use of the land but also had a duty to use the property at its highest and best potential use (and rental value):

A partial owner using this land for grazing or hay-cutting without compensation to the owners is not considered protecting the interests of the other owners. Neither would use by a partial owner for some purpose which denied the other owners benefit of a higher and better return. An example would be grazing use by partial owner when the tract could be leased for farming, industrial or commercial purposes. ${ }^{214}$

The requirement of rent for a co-owner's own use or possession of land is theoretically distinct from whether that co-owner even has use or possession rights in the first place. The IBIA's rent requirement did not change the threshold possession right. However, this implication that a co-owner may be required not only to pay fair rental value for his actual use but must also ensure the "high[est] and [best] return" possible from the property is novel and beyond the requirements of any traditional coownership rule. ${ }^{215}$ This is so even in jurisdictions where some rent is owed, and if applied in the Indian land context, such a heightened rent requirement may have created practical limitations to the exercise of otherwise informal co-owner possession rights. ${ }^{216}$

212. Cadotte v. Acting Aberdeen Area Dir., Bureau of Indian Affairs, 31 I.B.I.A. 175, 176 (1997); see also Thompson v. Acting S. Plains Reg'l Dir., Bureau of Indian Affairs, 54 I.B.I.A. 125, 130 (2011).

213. Id. The rent obligation is offset by the amount he or she owns, however. In other words, if a co-owner owned half of an allotment that was assessed with a rental rate of $\$ 100$ per month, that co-owner could offset that rent by 50 percent or her half ownership interest so that she owned the other co-owners' $\$ 50$ per month. See also Whiteman v. Billings Area Dir., Bureau of Indian Affairs, 25 I.B.I.A. 292, 293 (1994) (quoting BIA letter recognizing "the right of an Indian owner to make use of his own land provided the individual claiming the owner's use is compensating the other heirs ...."); Cadotte v. Acting Aberdeen Area Dir., Bureau of Indian Affairs, 31 I.B.I.A. 175, 176 (1997) ("The fact that Appellant owns an undivided interest in the allotment does not excuse his non-payment of rent.").

214. Whiteman, 25 I.B.I.A. at 293-94; see also Smith v. Acting Anadarko Area Dir., Bureau of Indian Affairs, 34 I.B.I.A. 283, 286 n.5 (2000) ("In no instances should an owner be permitted to conduct activities which commit waste.").

215. Cf. supra notes $24-25 \& 30-33$ and accompanying text.

216. The doctrine of waste, for example, only prohibits co-owners from interfering with the 


\section{V. "LANDOWNERS WITHOUT LAND"217}

Thus, already at the end of the twentieth century, there were some limits on an Indian landowner's remaining owner's use rights. Many coowners had to pay rent for their use of their own property, and a coowner seeking to make a non-agricultural use of her own property may have had stronger rights to do so if she received her interest by intestacy or devise than if she had purchased it. However, on the whole, there persisted some important and relatively informal Indian co-owner use and possession right. This changed in the twenty-first century, when even these remaining rights were effectively eliminated. This section covers the changes from 2001 to today that caused, at least by current federal law, Indian landowners to retain few, if any, of the rights and benefits of owning land.

\section{A. The 2001 Sea Change}

It took the Department of Interior a long time to draft final regulations implementing AIARMA. Beginning with an initial rulemaking in 1996, there was some back-and-forth within the Department of Interior regarding the proper scope of protected owner's use rights under AIARMA. Part of this issue related to whose owner's use rights were protected, because as the Department of Interior explained in making its initial proposal of AIARMA regulations in 1996:

[AIARMA] originally confirmed the rights of individual "allottees" to use their own property and negotiate their own leases and permits. (By contrast, the 1940 act [25 U.S.C. § 380] allowed the "heirs and devisees" of allottees to prevent us from exercising our broad grant of authority on heirship land, by putting the land to direct use or by entering into a lease or permit during a three-month negotiation period.). ${ }^{218}$

reasonable expectations of their co-owners. Inactive co-owners who make no effort to use the property themselves typically have no expectation in perfect management of the land for their benefit. See generally POWELL, supra note 18, §§ 56.01-56.12; MOYNIHAN \& KURTZ, supra note 24 , Ch. $9, \S 5$, at 282-86.

217. Brown, supra note 57.

218. Leasing and Permitting, 61 Fed. Reg. 30560-01, 30562-63 (proposed June 17, 1996) (revising 25 C.F.R. pt. 162). 
Despite this potential confusion about what Congress had meant by the carve out for pre-existing owner's use rights of "allottees," in its first proposed rule-making, the Department of Interior proposed a regulation that provided broad owner's use protections regardless of how the individual owner asserting those use rights acquired her interest. Under the first proposed rule implementing AIARMA, the BIA would "not grant a lease or permit... if the land is used by an individual Indian owner and the other owners are receiving a fair annual rental." 219 This was also consistent with the IBIA's interpretation of this statutory language later in that same year. ${ }^{220}$

Between the time of this first proposed rule recognizing and protecting some owner's use and possession rights for individual Indian landowners, regardless of how the co-owner came into that ownership, in 1996, and the Department of Interior's final rule in 2001, two major things happened. First, the Cobell litigation took on a life of its own. ${ }^{221}$ Secretary of Interior after Secretary of Interior was held in contempt of court and the Department was regularly ridiculed for its terrible management of, and inability to account for, many of the funds it held in trust for individual Indians (including lease revenues from allotted lands). ${ }^{222}$ Maintaining an improved paper trail for the Department of Interior's management of trust funds - and perhaps, trust assets, like the land itself-and demonstrating investment return from those assets took on a new importance. ${ }^{223}$ Perhaps because of this, the Department of Interior increasingly emphasized formal leasing of Indian lands as "one of the most effective ways" to meet its trust obligations to Indian landowners. ${ }^{224}$ Requiring a paper lease and further documentation of

\footnotetext{
219. Id. at 30566.

220. See Emm I, 30 I.B.I.A. 72,79 (1996).

221. See supra note 16 and accompanying text.

222. See, e.g., Merjian, supra note 16, at 620-21, 625-26.

223. John C. Sledd, Events Leading to the American Indian Probate Reform Act of 2004, Presentation at Montana State University Symposium (Apr. 12, 2007), at 8, available at https://www.iltf.org/sites/default/files/Events\%20Leading\%20to\%20AIPRA\%20\%28Sledd\%29.pdf ("Pressured by Cobell, reducing trust liability exposure became a major driver of Interior policy.").

224. 2006 LEASING HANDBOOK, supra note 208, at 2 (stating that although "there is no statutory requirement that Indian lands held in trust by the United States Government be leased, the Secretary of the Interior has a fiduciary obligation to ... make decisions concerning trust lands that are in the best interest of the Indian landowner," and "[o]ne of the most effective ways to meet these obligations is to put the land under lease."); see also Fort Berthold Land \& Livestock Ass'n v. Great Plains Reg'l Dir., Bureau of Indian Affairs, 35 I.B.I.A. 266, 277 (2000) (explaining that while the Department of Interior "has a trust responsibility to ensure that individual Indian landowners receive a fair annual rental rate for the use of their lands," the Department has only a more amorphous "duty-which does not, however, rise to the level of a trust responsibility - to assist in the
} development and maintenance of a healthy agricultural economy on reservations"). 
even a landowner's own use of the land, with the accompanying rent requirement to the other landowner beneficiaries, may have seemed especially appealing at this time as a mechanism to avoid further potential trust accounting liability. In fact, in a candid status report on its trust improvement process to the Cobell court in January 2002, the Department of Interior acknowledged that the degree of fractionation of Indian lands was hindering the Department's ability to perform its trustee function efficiently. ${ }^{225}$ This had at least two primary causes. One cause was the burdensome number of transactions and records to oversee. ${ }^{226}$ The second was that the Department had struggled with the conflict between 'owners' property rights and the Secretary's fiduciary duty and trust responsibility to both the Indian tribe and the individuals for the trust asset." 227 The Department worried that the Secretary was in an "awkward" and "conflict[ed]" position of battling competing interests, including record-keeping efficiency versus individual property rights. ${ }^{228}$

The second major intervening event between the 1996 proposed rule and the 2001 final rule was legislative. As fractionation spun exponentially more out of control on the ground (and with it Congressional fears of additional trust accounting liability as the bureaucratic burden of keeping track of all of these minute interests overwhelmed the Department of Interior), Congress focused its legislative efforts on consolidating and otherwise decreasing the number of small interests it needed to maintain. Between the initial proposed AIARMA leasing rules and the 2001 regulatory changes, Congress passed the Indian Land Consolidation Act Amendments of $2000 .{ }^{229}$ The Senate Indian Affairs Committee explicitly connected the Cobell breach of trust lawsuit - and the government's admission "that it is unable to account for the money generated from the use of the (allotted) land owned by these individuals"- to the 2000 ILCA Amendments, calling those amendments "the primary legislative contribution to this comprehensive, inter-governmental effort" to remedy the "most destructive legacies of the allotment era," including the continued

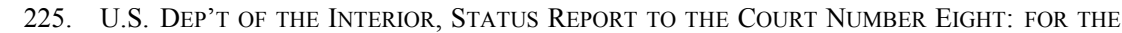
PERIOD Aug. 1, 2001 TO DEC. 31, 200158 (2002), available at http://www.doi.gov/ost/ trust_documents/upload/Quarterly_8.pdf.

226. Id.

227. $I d$. at 62 .

228. Id

229. Indian Land Consolidation Act Amendments of 2000, Pub. L. No. 106-462, 114 Stat. 1991 (codified as amended at 25 U.S.C. $\S \S 2201,2204-2207,2212-2219$ (2012)). Not all of these 2000 amendments were implemented. See Shoemaker, supra note 6, at $764 \mathrm{n} .175 \& 772$. 
fractionation of Indian lands "and its effect on the Federal government's ability to fulfill its trust obligation to Indian tribes and their members; the continuing loss of trust lands as it is inherited by non-Indians; and the effect of the allotment policy on Indian tribes. $" 230$

Like earlier versions of ILCA, many of the 2000 ILCA Amendments were aimed to promote consolidation or elimination of small fractional ownership interests. ${ }^{231}$ Perhaps more significantly for this purpose, however, the 2000 ILCA Amendments also adopted a sliding scale for the percentage of Indian landowners who must consent to a nonagricultural lease before the BIA would approve it. ${ }^{232}$ As in the case of the majority lease consent rule for agricultural leases in AIARMA, Congress in the 2000 ILCA Amendments was concerned that the Department of Interior's requirement of unanimous consent for an owner-approved third-party lease hindered investment because potential lessees would avoid the high transaction costs of assembling perfect coowner agreement.

Specifically, ILCA imposed a sliding scale system for the total percentages of co-owners' trust interests required to consent to a nonagricultural lease of an allotment, depending on the level of fractionation. The "minimum consent" requirement for these "non-agricultural" leases

230. S. REP. NO. 106-361, at 12 (2000).

231. The original Indian Land Consolidation Act was approved on January 12, 1983. Indian Land Consolidation Act of 1983, Pub. L. No. 97-459, 96 Stat. 2515, 2517-19 (1982) (codified at 25 U.S.C. $\S \S 2201-2210$ (1982)). It was also amended in 1984. Indian Land Consolidation Act Amendments of 1984, Pub. L. No. 98-608, 98 Stat. 3171 (1988) (codified as amended at 25 U.S.C. $\S \S 2203-2206,2211$ (2012)). Initially, Congress sought to force the escheat of the smallest of these individual ownership interests to the governing tribe upon the owner's death, but the Supreme Court held this was an unconstitutional taking of Indian landowners' "right to devise." Hodel v. Irving, 481 U.S. 704 (1987). Importantly, this escheat provision was also ineffective. U.S. GEN. ACCOUNTING OFFICE, GAO/RCED-92-96BR, PROFILE OF LAND OWNERShIP AT 12 RESERVATIONS, at 1-2 (1992) (describing how two more times as many small fractional interests were created than the number that would have qualified for escheat under ILCA, even if it had been carried out constitutionally). The ILCA also attempted to provide mechanisms for an individual's tiny interests in a property to be consolidated (through tribal exchange programs or tribal purchase options) and sought to create more uniformity and simplicity in intestacy, with the option for tribal probate codes as well. See Shoemaker, supra note 6, at 764-74. However, these programs were also hyper formal and overly complex and therefore often ineffective. For example, the director of the Land Office at the Pine Ridge Reservation reported in June of 1995 that the procedure required for a landowner to accomplish one of these ILCA exchanges included at least nine separate steps (including various approvals from multiple different offices and administrative levels) and took up to six years for a landowner to complete. Carl G. Hakansson, Allotment at Pine Ridge Reservation: Its Consequences and Alternative Remedies, 73 N.D. L. REV. 231, 251 n.165, 256-59 (1997).

232. These ILCA changes were specifically not intended to change the Department of Interior's interpretation of AIARMA, however, which was theoretically the subject of the 1996 and 2001 rulemakings. For example, there is a rule of construction that these ILCA and AIPRA sliding scales shall not be read to amend or modify AIARMA. 25 U.S.C. § 2218(f) (2012). 
was based on a sliding scale. ${ }^{233}$ A bare majority of interests was required for tracts with 20 or more Indian owners but unanimous consent was required for tracts with five owners or fewer. ${ }^{234}$ Importantly, unlike AIARMA, ILCA did not contain a parallel reservation or mention of protecting any pre-existing owner's use rights. ${ }^{235}$ Instead, ILCA expressly provided that a lease approved by the requisite percentage of fractional trust interests shall be binding upon all of the co-owners of the allotment. ${ }^{236}$ Thus, on its face, this reform could be interpreted to bind even any co-owners who may have desired to use the land themselves if the requisite percentage of other co-owners agrees to the alternative course, and this leaves a co-owner in possession none of the priority or veto rights that were arguably protected under AIARMA. ${ }^{237}$ This new rule might be read to allow absentee owners - at least in non-agricultural contexts - to evict (effectively) a co-owner in possession merely by executing a lease to another party without the in-tenant's permission (assuming they have a sufficient percentage of the other trust interests consenting to the lease). ${ }^{238}$

233. Indian Land Consolidation Act Amendments of 2000 sec. 219 , 25 U.S.C. $§ 2218$.

234. Id. The unanimous consent rule for five or fewer owners was reduced to a 90 percent consent requirement in 2004. See 25 U.S.C. $\S 2218$ (b) (effective Sept. 7, 2004). The BIA also has the authority to vote on behalf of missing or undetermined co-owners. § 2218(c); see also S. REP. No. 106-361, at 23 (discussing decision to employ graduated scale because AIARMA's majority rule had not yet been implemented in final rules by BIA); Indian Land Consolidation Act Amendments; and to Permit the Leasing of Oil and Gas on Navajo Allotted Lands: Hearing on S. 1586, S.1315, and H.R. 3181 Before the S. Comm. On Indian Affairs, 106th Cong. 162 (1999) (statement of Delmar Poncho Bigby, Chairman, Indian Land Working Group) (proposing slidingscale consent requirement to replace original majority rule provision).

235. S. ReP. No. 106-361, at 12; see also Presidential Statement on Signing the Indian Consolidation Act Amendments of 2000, 36 WeEKLY COMP. Pres. Doc. 45 (Nov. 7, 2000), available at http://www.gpo.gov/fdsys/pkg/WCPD-2000-11-13/pdf/WCPD-2000-11-13-Pg28112.pdf (legislative purpose was to "enhance opportunities for economic development").

236. Indian Land Consolidation Act Amendments of 2000 sec. 219, 25 U.S.C. $\S 2218$ (providing that lease is "binding on" non-consenting co-owners); see also S. REP. NO. 106-361, at 23.

237. See supra Part IV.C.3.

238. It is not at all clear that this issue was fully vetted and the impact of leasing rules on landowners' rights actually considered by Congress. However, in the Senate Committee on Indian Affairs report on the legislation, the Committee noted that one of the few instances in which it could foresee an Indian landowner wishing to devise land to multiple devisees was "where the deviser is in a position to confer 'use rights' upon several heirs who are making use of the land." S. REP. NO. 106-361, at 13. This suggests some understanding of "use rights" still existing as of that time. Nonetheless, the final legislative policy statement in the amendments themselves provided that Congress should "prevent the further fractionation of trust allotments," without any express discussion of preserving co-owner's use rights. Indian Land Consolidation Act Amendments of $2000 \mathrm{sec} .102(1), 25$ U.S.C. $\S 2201$. 
However, even this possible implicit impact on co-owner's use and possession rights under the 2000 ILCA Amendments is relatively limited. First, it applies on its face only to non-agricultural uses. Second, it would only usurp or trump a co-owner's direct use and possession rights, if at all, where a coordinated majority or larger cohort of the other co-owners have organized and actively decided to lease the property to another. Nothing about the 2000 ILCA Amendments on their face impacted a co-owner's use and possession rights in the much more common scenario where the co-owners have not so organized themselves and agreed to pursue an alternative path, where the land is otherwise idle, or where the BIA is the party seeking to grant the lease where there is no co-owners' consent and the land is not otherwise in use by a co-owner under the 1940 Act.

Nonetheless, in January 2001, the Department of Interior adopted much more sweeping restrictions on owner's use rights in new leasing rules that not only applied AIARMA but also incorporated the outputs of its broader trust accounting reform process. ${ }^{239}$ Although the 2000 ILCA Amendments had been passed by the time of this final rule, the Department of Interior stated in January 2001 that it would need more time to "fully ascertain" the ways in which the 2000 ILCA Amendments "extensively alter[ed] the legal framework governing activities on fractionated trust and restricted lands" and thus promised more regulations incorporating those changes in the future. ${ }^{240}$

In proposing these new 2001 rules six months prior, the Department of Interior stated that it "recognizes the unique burdens placed on potential users of fractionated land," and requested comments on a new "owner's use" regulation that would require any co-owner of Indian land "obtain a lease from all co-owners of the land before using the land exclusively for his or her own purposes." 241 The Department explained it was considering this requirement "[i]n order to provide maximum protection for all trust property beneficiaries." 242 In the final rule in 2001, the Department of Interior adopted this owner's use restriction:

239. See Trust Management Reform: Leasing/Permitting, Grazing, Probate and Funds Held in Trust, 66 Fed. Reg. 7068-01, 7069 (Jan. 22, 2001) (to be codified at 25 C.F.R. pt. 15, 114, 162, 166) (describing in greater detail process of drafting new rules as part of sweeping "Trust Management Improvement Project").

240. Id. at 7068 (leaving open new regulations on business and residential leases specifically).

241. Trust Management Reform: Leasing/Permitting, Grazing, Probate and Funds Held in Trust: Notice of Proposed Rulemaking, 65 Fed. Reg. 43874-01, 43874-75, 43881 (July 14, 2000) (describing new proposal for what it termed the "owner's use" rule at proposed 25 C.F.R. § 162.67).

242. Id. at 43881 . 
Many questioned whether the individual Indian landowners of undivided interests in fractionated tracts would need leases from their co-owners (i.e., "owner's use"), before taking possession. In response, [25 C.F.R.] § 162.104(b) clarifies that an Indian landowner of an undivided interest may not take possession without a lease unless the Indian co-owners give their permission. ${ }^{243}$

In that same paragraph, the Department of Interior also references that it was not accepting commentators' requests to eliminate this requirement because "[t]his provision is necessary to ensure protection for, and to foster cooperation and negotiation among, all Indian co-owners."244

Thus, after this 2001 change, the Department of Interior began explicitly requiring a lease or some other form of actual permission from the other co-owners before an owner could take possession of any portion of the property. The actual final regulation adopted by the Department of Interior, Section 162.104(b), provided:

An Indian landowner of a fractional interest in a tract must obtain a lease of the other trust and restricted interests in the tract, under these regulations, unless the Indian co-owners have given the landowner's permission to take or continue in possession without a lease. ${ }^{245}$

The Department of Interior applied this regulatory change to all types of leases and all manners of lease creation. Thus, even though AIARMA specifically provided that it should not be construed "as limiting or altering the authority or right of an individual allottee ... in the legal or beneficial use of his, her, or its own land," this rule changed arguably changed those rights. ${ }^{246}$

The Department of Interior also applied this new prior-permission concept to its interpretation of the scope of its authority under the 1940

243. Trust Management Reform: Leasing/Permitting, Grazing, Probate and Funds Held in Trust, 66 Fed. Reg. at 7081 (emphasis added).

244. Id. It is unclear who made the "requests to eliminate the owner's use provision in its entirety" referred to in this response. The public comments from this rule-making are not archived on regulations.gov nor are they readily available electronically by request to the National Archives. However, it appears by implication that there were objections to this new owner's use provision from the 2000 Proposed Rule limiting co-owner's use rights in this way, just as there were to further reforms in this direction in 2013. See, e.g., infra note 261 and accompanying text.

245. 25 C.F.R. $\S 162.104$ (b) (2002) (recodified as amended at 25 C.F.R. $\$ 162.005$ (2013)). The substance of this rule, with some minor modifications, was moved to 25 C.F.R. $\S 162.005$ in regulatory changes in 2013. See infra note 256 and accompanying text.

246. 25 U.S.C. $\S 3715(c)(1)$ (2012). Perhaps in light of this, there is a special rule for agricultural leases, also adopted in 2001, that if a majority of co-owners seek to approve a new lease to agricultural land while another co-owner is currently using it, that co-owner in possession must be given a right of first refusal to lease the land. 25 C.F.R. § 162.207(c) (2014). 
Act. As the Department of Interior explained in the regulatory preamble to the 2001 rule change:

Many respondents questioned the proposed provisions that addressed the granting of leases on fractionated tracts, including "owner's use" leases .... Section 162.209(b) provides that we will not exercise our authority under 25 U.S.C. $§ 380$ [the 1940 Act] to grant a lease on behalf of all of the Indian owners of a fractionated tract where the Indian co-owners have given one of the Indian landowners permission to possess the tract without a lease.

Under this new interpretation, for the first time, "permission" from the other co-owners is specifically required before an owner in possession will be able to preclude the BIA from executing a lease on behalf of the owners who otherwise cannot agree to a lease to another.

Moreover, although this regulation suggests that informal permission as opposed to a formal lease may suffice, and perhaps even something as informal as acquiescence could bestow an owner's use right, subsequent IBIA decisions clarified that a formal lease may be required in every instance. ${ }^{248}$ In fact, an emphasis on formal leasing relationships among co-owners, as opposed to any pre-existing use arrangements, worked its way into several IBIA decisions. For example, in one decision a coowner was living on her own allotment pursuant to a lease, but it expired too soon to enable her to access a leasehold mortgage. ${ }^{249}$ She sought an amendment to extend the lease term and it was denied by the BIA. ${ }^{250}$ The co-owner complained to IBIA that the regional office had previously permitted co-owners to use their allotments as residences without a lease and that there were in fact others living on her allotment without residential leases. ${ }^{251}$ The IBIA rejected this prior practice and advised the co-owner that her remedy was not to have her own residential lease amendment approved informally, "but rather to seek action from the BIA to remove those persons from the allotment or to obtain proper leases."252 Ironically, the IBIA noted that "[t]he Board has found that individuals can be quite creative in the ways they resolve disagreements when given

247. Trust Management Reform: Leasing/Permitting, Grazing, Probate and Funds Held in Trust, 66 Fed. Reg. at 7082 (emphasis added).

248. Spang v. Rocky Mountain Reg'l Dir., Bureau of Indian Affairs, 52 I.B.I.A. 143, 143-44 (2010) (rejecting Indian co-owners request for flexibility in leasing requirements because even Indian co-owners must "obtain a lease of the other trust and restricted interests in the tract").

249. Chicharello v. S. Plains Reg'l Dir., Bureau of Indian Affairs, 39 I.B.I.A. 195, 195 (2003).

250. Id. at 195-96.

251. Id. at $197-98$ \& n.6.

252. Id. at 198 n.6. 
the opportunity," but held that the BIA's leasing rules and statutes applied to co-owners without much, if any, flexibility or room for creativity. ${ }^{253}$

Thus, after the dust settled on the Department of Interior's interpretation of AIARMA, Indian co-owners of land no longer had any recognized right to initiate informal use of one's own property without some prior permission or lease from the co-owners. Previously, both the Department and the IBIA had concluded that AIARMA did not permit a majority of co-owners to lease an allotment out from under a rent-paying co-owner currently in possession. Furthermore, they both initially concluded that a co-owner's use and possession of land also preempted the BIA from leasing that land out on behalf of the other co-owners, regardless of how the in-tenant came to own his interest in the allotment. Despite this, the Department of Interior's 2001 regulations effectively changed those interpretations. Open questions remained, however, about precisely what owner's use rights remained, if any, and how the Department of Interior's interpretation of the 2000 ILCA Amendments might change this result.

\section{B. The 2013 Rules Make Problems Worse}

As promised, the Department of Interior finalized additional new surface leasing regulations effective January 4, 2013. ${ }^{254}$ Overall, these new regulations were intended to make leasing procedures for residential, business, and wind and solar resources (i.e., non-agricultural leases) as "explicit and transparent as possible." 255 However, the new regulations make some additional significant changes for owner's use rights. Although the new 2013 regulations say on their face that they do not apply to agricultural leases, which are still subject to the 2001 rules, in reality it seems the Department of Interior must be applying the "general" rules from the 2013 regulations to agricultural leases as well. For example, certain "general" rules from the 2001 rules, including the new 2001 owner's use rule itself, were deleted and moved to a new "general provisions" rule in the 2013 regulations to "delete

\footnotetext{
253. Id. at 199; see also 2006 LEASING HANDBOOK, supra note 208, at 11 (explaining that while an "Indian landowner has the right to use their trust or restricted property" the 2001 regulation requires a co-owner of land to "obtain permission or a lease to continue to use the land").

254. Residential, Business, and Wind and Solar Resource Leases on Indian Land, 77 Fed. Reg. 72440-01 (Dec. 5, 2012) (to be codified at 25 C.F.R. pt. 162).

255. Id. at $72440-41$.
} 
redundancies." ${ }^{, 256}$ In any event, the new 2013 regulations do several things. First, they clarify that the Department of Interior now requires full 100 percent co-owner permission before a co-owner may take possession without a lease even where the land is not otherwise in use. ${ }^{257}$ Second, they further limit the 1940 Act's owner's use protections by extending them only to sole owners of 100 percent of a property as opposed to any co-owner heir. ${ }^{258}$ And third, they generally provide even greater protections for absentee landowners by mandating fair-market value rent returns even where the other, active landowners affirmatively agree to a lease on different terms. ${ }^{259}$

To start, these new regulations clarify that any "Indian landowner of a fractional interest in the land" must obtain a lease "from the owners of other trust and restricted interests in the land" in order to possess that land "unless all of the owners have given you permission to take or continue in possession without a lease." 260 Whereas the 2001 regulations provided more vaguely that a co-owner must have some degree of "permission" from her Indian co-owners to take possession without a lease, the 2013 regulations clarify that co-owner possession without a lease requires unanimous co-owner permission. Of course, in a traditional tenancy in common, no such pre-possession permission is required at all, and the National Congress of American Indians and

256. Id. at 72440, 72474; see also 25 C.F.R. § 162.002(b) (2014) (providing "General Provisions" part of new rules does not apply to agricultural leases). But see 25 C.F.R. $\S 162.005$ (2014) (moving the only owner's use rules to this "General Provisions" section). It seems this issue was not fully considered in the regulatory drafting, causing confusion. E.g., 25 C.F.R. $\S$ 162.209(b)(2) (2014) (continuing to reference now-deleted 25 C.F.R. § 162.104(b) (2002) (recodified as amended at 25 C.F.R. $§ 162.005$ (2013)); see also 25 C.F.R. $\S 162.106$ (a) (2014) (continuing to suggest that agricultural trespass can only occur where "possession is taken without an agricultural lease by a party other than an Indian landowner of the tract").

257. See 25 C.F.R. $\$ 162.005$ (a) (2014).

258. See 25 C.F.R. $\S 162.013(\mathrm{c})(6)$.

259. See, e.g., 25 C.F.R. $\S \S 162.207$ (c), $162.421(\mathrm{e}), 162.550$. The new rules also, for the first time, categorically exempt "permits" for short-term non-possessory, revocable rights for some limited uses of Indian land from BIA approval, administration, and enforcement authority. See Residential, Business, and Wind and Solar Resource Leases on Indian Land, 77 Fed. Reg. at 72444 45; 25 C.F.R. § 162.007 (2014). By removing some "permits" on Indian allotments from BIA oversight and control, this new rule may also implicitly affirm more local control of temporary uses of Indian land, including potentially uses by Indian owners themselves. The new rule, however, defines these more flexible "permits" narrowly such that they are not considered an interest in land, and grazing and other specified types of common "permits" are still treated separately and are subject to extensive BIA oversight and control. See Residential, Business, and Wind and Solar Resource Leases on Indian Land, 77 Fed. Reg. at 72444-45; see also 25 C.F.R. $\S \S 163.1-.83,166.1-$ .1001 (separate regulatory section for timber and grazing permits). This is an area for future analysis that warrants more work going forward.

260. 25 C.F.R. § 162.005(a) (2014) (emphasis added). 
others pointed this out to the Department of Interior, arguing that each co-owner "has full rights to use the property in any manner" and there was "no authority in federal law for BIA to diminish the property rights of each Indian co-owner and to require co-owners to pay rent for the use of their own property."261

The Department of Interior rejected this property-rights argument by noting (non-responsively) that their chosen regulation permits a "coowner to use the tract if the other fractional co-owners agree."262 The Department of Interior also stated:

We disagree with the commenters' claim that each owner has full rights to use the property in any manner, because one co-owner does not have the right to exclude the others without their consent. For this reason, we reject the commenters' claim that requiring a lease is diminishing the property rights of each co-owner by requiring him or her to pay rent for use of his or her own property. ${ }^{263}$

This answer is circular and fails to recognize that in fact co-owners do have a right to possess the entirety of a property, separate from whether they may also have to pay a proportionate rental value for that possession. In the non-Indian context, the rule that one co-owner cannot exclude another co-owner is managed through the ouster doctrine after there is an actual conflict between two active co-owners, not by requiring each co-owner to get affirmative permission from all co-owners (both active and inactive) before they take any possession of the land.

The Department of Interior also explained that its intent in permitting co-owners to get "permission" from all other co-owners as opposed to requiring a full BIA-approved lease was to "provide... maximum flexibility by allowing for informal agreements." 264 On its face, this is an attempt to offer a "permission" route that is less onerous than the formal leasing process-however, this fails. For example, a party seeking a lease of an allotment needs only consent from a sliding scale percentage of trust interests in the allotment. However, in order to avoid a lease and take possession using this alternative route as a co-owner of the land, the co-owner must get unanimous consent from all of the other co-owners. In addition, the Department of Interior itself has acknowledged that significant numbers of co-owners are missing or their estates are still

261. NCAI Comments, supra note 15, at 3; see also NCAI Resolution, supra note 15.

262. Residential, Business, and Wind and Solar Resource Leases on Indian Land, 77 Fed. Reg. at 72444 .

263. Id.

264. Id. 
pending in the probate queue. However, under the rules, the BIA may only consent on behalf of those unidentified or missing co-owners in a formal lease, and presumably not in a more informal permission for coowner's use. ${ }^{265}$

Second, the regulations dramatically reduce the effect of the 1940 Act. As discussed above, this 1940 Act permits the Department of Interior to grant leases on behalf of the Indian owners only when such "lands are not in use by any of the heirs." ${ }^{266}$ Prior to these new regulations, this Act had been interpreted as protecting a co-owner who is in current possession of an allotment from having the land leased out to another party by the BIA, typically without requiring any kind of prerequisite permission or approval for that owner's use. This is also consistent with the plain language of the Act that protects "use by any of the heirs." 267 Nonetheless, the 2013 regulations now provide that the BIA may grant a lease on behalf of Indian co-owners "of a fractionated tract" whenever the landowners had notice of the BIA's intent to execute that lease, failed to agree to a lease during the three-month negotiation period, and the land is not being used by an Indian landowner who owns 100 percent of the land and is making use of it. ${ }^{268}$ Instead of any heir's or devisee's use preempting BIA authority, this new interpretation bizarrely limits the meaning of "any of the heirs" in the 1940 Act to only the one heir who owns the entire property exclusively. ${ }^{269}$

Finally, there are several other indirect changes that impact what little is left of an owner's use right. Notably, under the 2013 regulations, there continues to be a significant level of protectiveness for nonconsenting or absentee landowners. For example, where a sliding-scale percentage of landowners consents to the lease under ILCA and thereby binds non-consenting owners, ${ }^{270}$ the non-consenting owners in those

265. 25 C.F.R. $\S 162.013$ (c) (2014) ("BIA may give written consent to a lease ...." (emphasis added)).

266. 25 U.S.C. $\$ 380(2012)$

267. Id.

268. 25 C.F.R. $\S 162.013(c)(6)$ (2014). Specifically, the regulation references use by a "landowner" defined under $\S 162.005(\mathrm{~b})(1)$, which is a landowner who owns 100 percent of the tract.

269. The illogical nature of this rule is further highlighted by the fact that the regulation itself purports to apply to leases of a "fractionated tract," but by definition a fractionated tract would never have a sole owner making use of the land because to be "fractionated" tracts must have more than one owner. This suggests there may be some unintentional Department of Interior error in the framework adopted here, but because the BIA also now requires that an owner have 100 percent permission or a formal lease before instigating "use" of the property, this issue may never get clarified. See also supra note 256.

270. 25 C.F.R. $\S 162.012(a)(4)(i)$ (2014). 
formulas typically are still entitled to fair-market-value rent, even if the lease to the consenting owners is for less than that amount. ${ }^{271}$ These regulations also make it more difficult for co-owners to agree to leases for less than fair-market-value rent. For example, the new residential leasing rules require residential lessees of individually owned Indian land to pay "not less than fair market rental" value. ${ }^{272}$ Residential leases for nominal rent or less than fair market value may only be permitted if 100 percent of the landowners execute a written waiver of their right to receive fair market value - meaning that generally a lease to a co-owner cannot be for less than fair market value unless every single interest owner agrees (and it is not clear that BIA could ever agree to these lesser-rent amounts on behalf of any missing or unidentified coowners). ${ }^{273}$ Even the appraisal requirement generally cannot be waived without 100 percent of the landowners' consent. ${ }^{274}$ Because at least one tribe complained about what these new rules would do to co-owners of allotments who had purchased houses on their jointly owned allotments without any formal lease from their co-owners under earlier interpretations of their co-owner's use and possession rights, the final rule does include a provision permitting some co-owners who resided on a tract for at least seven years prior to January 2013 to be grandfathered in without an obligation to pay non-consenting landowners fair-marketvalue rent, but only if no other co-owner objected to that arrangement before July 2013 . $^{275}$

According to the regulatory comments, several tribes objected to this protection for non-consenting and absentee owners. They worried about "real-world constraints" and the fact that the strict fair-market-value requirements are "not feasible in many circumstances," especially in light of the Indian housing problem more generally. ${ }^{276}$ In response, the Department of Interior missed the point by saying that "all Indian landowners are entitled to just compensation for use of their land (and a

271. See 25 C.F.R. $§ 162.207$ (c) (non-consenting owners of agricultural lease "must receive a fair annual rental"); 25 C.F.R. $\S 162.421$ (e) (non-consenting owners and those on whose behalf the BIA consented must "receive a fair market rental, as determined by a valuation" for business lease); 25 C.F.R. $\S 162.550$ (same for wind or solar resource lease).

272. 25 C.F.R. $\S 162.321(\mathrm{a})$.

273. Id.

274. 25 C.F.R. $\S 162.321(b)$

275. 25 C.F.R. $\S 162.321$ (c). There are also some special conditions for co-owner leasing of business leases. 25 C.F.R. $§ 162.421$ (b).

276. Residential, Business, and Wind and Solar Resource Leases on Indian Land, 77 Fed. Reg. 72440-01, 72450-51 (Dec. 5, 2012) (to be codified at 25 C.F.R. pt. 162). 
valuation is required to determine what just compensation is), not just consenting landowners." 277

\section{VI. "FIVE, SiX, PICK UP STICKS”: What COMES NeXT}

It is hard to imagine a property system or co-ownership framework better designed to ensure individual co-owners do not make use of their own property. Under current rules, any Indian owner seeking to make use of his or her own land has no preemptive possession rights unless he or she owns 100 percent of the land. Any co-owner must now get unanimous permission from his or her other co-owners or a formal BIAapproved lease before taking possession. In many cases, the BIA may grant a lease to another party even when a co-owner is already in possession of the land. And in some cases, a sliding scale percentage of the other co-owners may also be able to lease the land out from under a current in-tenant. There is no efficient partition, ouster, or other stable exit mechanisms for dissatisfied co-owners. Even if a co-owner could somehow get through the necessary process to acquire her co-owners' consent to possess the land, she must pay her co-owners at least fair market value for that possession - and that fair-market-value might be based not on her actual use but on the highest and best possible use to which the land could ever be put.

Meanwhile, instead of maximizing the values of these lands and encouraging active co-owner cooperation, the federal government's coownership framework may instead be incentivizing inaction by absentee landowners and, by extension, continued fractionation of these Indian lands at federal and taxpayer expense-and most importantly, at the expense of Indian communities who cannot unlock the full potential of their lands. Under the current system, absentee or uninterested landowners face no real cost for continued ownership of ever smaller and smaller interests. There are effectively no pro rata shares of taxes, maintenance, or administration costs to be shared among co-owners, and absent any real risk of land loss, there is no incentive to coordinate actively with co-owners to avoid partitions, foreclosures, or other forced sales. ${ }^{278}$ Instead, Indian co-owners who refuse to cooperate with their

277. Id. at 72451; see also id. at 72456 ("“A]11 non-consenting landowners are entitled to fair market value, as our trust responsibility is to all landowners, not just those who have consented.... Each individual can waive his or her own right to receive fair market rental; however, even if a majority waives their right to fair market rental, they may not waive the right of the other, nonconsenting owners to fair market rental.").

278. The fact that administration costs of land held in trust are borne by the federal government 
other co-owners have the significant advantage. The absentee landowner will likely be rewarded under BIA rules with the highest financial return from inaction because the BIA may step in and lease the allotment for the co-owners at the highest available market rate. Or, if he refuses to participate in leasing the land and free rides on his co-owners making a lease agreement on their own, that absentee landowner is rewarded with fair-market-value rental returns even if the active, negotiating landowners got less. Instead of incentivizing consolidation, and coowner cooperation, this system encourages continued passive fractionation and an ever-expanding BIA land management program.

The irony here is glaring. The very system sold as "giving" property rights to Indian people over a hundred years ago has actually taken their property away. ${ }^{279}$ This occurred historically through surplus land sales, fee patents, and other forms of outright Indian land loss. Now, the complexity of the resulting modern tenure system is also eliminating Indian property rights on the lands that remain, including the most important right to possess their own land. Although recent regulatory reforms were likely executed with at least some good intention to protect the interests of all trust beneficiaries at a time of crisis for the federal trustee function, this quiet loss of Indians' co-owner property rights is worth greater exploration and debate. The trust status that was intended to support and protect new Indian owners in their status as part of a community of active landowners is becoming more like a bean-counting system of dwindling returns far removed from real property rights. Indian landowners are more like minor shareholders with only paper rights to a commodity over which they have very little control - all at the expense of local property rights. This does not seem to be in the best interest of the community of landowners within indigenous nations or for anyone who contributes to the federal government's continued investment in this counter-productive system.

This elimination of indigenous possession rights over time raises a host of important legal issues. This section begins to explore some of these challenges and concerns but concludes, most fundamentally, that work must be done at a tribal level, with full and adequate federal

leads to "inertia and opposition of some of the Indians themselves" as it creates "a situation particularly attractive to persons with small interests who are content to receive small returns with little effort." Williams, supra note 167, at 725.

279. See also Angelique Townsend Eaglewoman \& Stacy L. Leeds, Mastering AMERICAN INDIAN LAW 30 (2013). 
support, to create a more rational system of Indian land tenure in which individual Indians can realistically and flexibly make use of their own land. This section proceeds by first highlighting some of the potential of informal owner's use arrangements, even in highly fractionated conditions. Then, it addresses the need for tribally driven solutions followed by some discussion of the reasons the federal government must respond accordingly to facilitate this transition to a system of owner's use in a locally congruent way.

\section{A. The Promise and Potential of Owner's Use}

Indian lands are not the only resource held by an otherwise disenfranchised group to suffer from extreme fractionation concerns. For example, "heir property" is prevalent among African Americans in the South and certain families in Appalachia, both communities who experience an overall failure of access to the probate process. ${ }^{280}$ The risk of land loss for these co-owners is high, and title is relatively insecure. Landowners must coordinate, among themselves and without the assistance of any kind of federal trustee or facilitator, to bear and allocate the shared costs of ownership, including for example property tax or lien obligations, or they risk foreclosure or other forced sales of the land. ${ }^{281}$ In addition, any defecting co-owner may unilaterally force a partition. ${ }^{282}$ Because of the number of co-owners in these properties, this usually results in a forced partition sale, with pre-existing co-owners unable to aggregate the resources to redeem the property. ${ }^{283}$

Indian lands, with their restraints on alienation, the trustee to perform administrative and record-keeping tasks, and exemption from state property tax and other similar costs of maintaining fractionated ownership interests, do not share these same risks. However, while insecurity is an important concern for other types of heir property coowners, they do have some advantages over their Indian counterparts. Most notably, the broad possessory rights for all co-owners in non-Indian tenancies in common leave an option for, or even a preference of, a local

280. See, e.g., Janice F. Dyer \& Conner Bailey, A Place to Call Home: Cultural Understandings of Heir Property Among Rural African Americans, 73 RURAL Soc. 317 (2008); Jess Gilbert, Gwen Sharp, \& M. Sindy Felin, The Loss and Persistence of Black-Owned Farms and Farmland: A Review of the Research Literature and Its Implications, 18 S. RURAL Soc. 1 (2002); B. James Deaton, Intestate Succession and Heir Property: Implications for Future Research on the Persistence of Poverty in Central Appalachia, 41 J. OF ECON. IsSUES 927 (2007).

281. See, e.g., Mitchell, supra note 11, at 517-21.

282. See, e.g., supra note 41 and accompanying text.

283. See Mitchell, supra note 11, at 517-21; Mitchell, supra note 41, at 614-19. 
owner's use of his or her own land, and therefore preserve a pathway for informal use arrangements among co-owners. Thus, in heir property examples in the South or in Appalachia, there are several concrete case studies of landowners who appreciate the informality of possession rights that permit self-help arrangements for use among owners in shared possession. ${ }^{284}$ These default rules permit internal, place-specific arrangements among co-owners for owner's use of the land where exclusive, individual land ownership may not be feasible or desired. Maintaining this mechanism for flexible, place-specific arrangements for shared use incentivizes land stewardship and development of the land by the owners themselves, and also puts some onus on the non-possessing owners to monitor and actively interact with their lands and co-owners if they want to influence its use.

Of course, it is this informal possession right that is entirely missing from most Indians' experience. However, because of a few idiosyncratic quirks of Indian law and history, there are a small handful of tribes who escaped application of some of the top-down federal tenure rules for individually owned Indian trust property, including allotment itself, and these tribes do demonstrate some of the benefits associated with a retained informal use right. For example, the tribes of the arid southwest largely escaped allotment because, in that climate and landscape, federal officials acknowledged that "tribes such as the Navajo had to live communally to survive," and "[t]hese nomadic herdsmen who followed the grass and rain could not exist on 80 or even 320 acres." 285 Therefore, the Navajo today still operate with some of their own indigenous property systems and tenure rules on remaining reservation lands. Many "families are organized in 'camps' consisting of several generations" with "[c]lustered housing-mobile homes, hogans, and/or frame built houses and sheds" and a sharing of work, meals, and resources in a culturally cognizant way that has proven effective to some degree in reducing some of the effects of poverty that are otherwise felt on other reservations. ${ }^{286}$ The Navajo Nation recognizes these internally managed property rights as an unrecorded but valid jointly-owned customary use

284. See, e.g., J. F. DYer, Heir Property: Legal and Cultural Dimensions of Collective Ownership, in BULLETIN 667 (Ala. Agric Experiment Station, 2007), http://www.aaes.auburn.edu/ comm/pubs/bulletins/bull667.pdf (describing African American farmers in the South who appreciate the informality of locating multiple family homes on jointly owned property); see also Deaton, supra note 280 .

285. MCDONNELL, supra note 104, at 8 .

286. Ezra Rosser, This Land is My Land, This Land is Your Land: Markets and Institutions for Economic Development on Native American Land, 47 ARIZ. L. REV. 245, 257, 263 (2005); see also Bobroff, supra note 77, at 1596-97. 
right that is protected against other development-just as many indigenous Indian property institutions did originally - and today the Navajo are one of the most economically successful and independent of the Indian nations. ${ }^{287}$

Likewise, a lack of clarity about the Department of Interior's interpretation of its individual Indians' property rights before the 2001 and 2013 rules led to some different practices at different BIA agencies until recently. Thus, when the Department of Interior was considering its 2013 leasing regulations requiring co-owners to have leases or 100percent owner consent before taking possession of their own land, even for a residence, and requiring rent payments to other co-owners in almost every case, the Salt River Pima-Maricopa Indian Community complained bitterly that Indian landowners were being required to "rent[] their own land" and this did "not reflect the reality of reservation life." 288 According to the Salt River comments, various federal, state, and tribal programs from 1960 to 2003 had assisted individual Indians to build homes in their area on their jointly owned Indian lands, with no requirement of a formal lease. These individual Indian landowners were living on these lands, in homes they had long since paid for, without a formal lease from their co-owners. ${ }^{289}$ As one individual citizen of the Salt River community told the Department of Interior, sharing land with immediate family members living next door was part of his "[h]eritage as a [t]ribe," and he and his family members "wanted to live the rest of our lives on our land." 290 This landowner worried that obtaining signatures of all of the co-owners, where many of his family members had already died, "would be next to impossible," and "[h] $[\mathrm{h}$ aving to pay rent to live on our own land would create a tremendous hardship not only for myself but for everyone involved" and would "change relationships and the culture of our families and of this Community."291

Of course, although not perfect, these kinds of flexible, individual use rights and local arrangements were also inherent in historic indigenous tenure systems. At least some of these indigenous systems

287. Rosser, supra note 286, at 263.

288. Comment of Diane Enos, President of Salt River Pima-Maricopa Indian Community, to Del Laverdure, Principal Deputy Assistant Sec'y of Indian Affairs (Jan. 27, 2012), available at http://www.regulations.gov/\#!documentDetail;D=BIA-2011-0001-0024.

289. Id

290. Comment of Enrolled Member of the Salt River Pima-Maricopa Indian Community, to Del Laverdure, Principal Deputy Assistant Sec'y of Indian Affairs (Jan. 25, 2012), available at http://www.regulations.gov/\#!documentDetail;D=BIA-2011-0001-0011.

291. Id. 
included their own efficient mechanisms to prioritize management of jointly owned lands by active, present co-owners who maintained a physical connection to the land and also provided a seamless exit mechanism for departing landowners. ${ }^{292}$ Indeed, as far back as 1934, when Congress and others were realizing the devastation that was being wrought by allotment, some voices in government were already looking longingly back at the kind of indigenous Indian land tenure systems in place before allotment. These government officials argued that the model for future land tenure decisions in Indian Country should be "derived from the example of those Indian reservations which had not been broken up and allotted, reservations in which all of the land remained in common ownership, hence was safe against loss, while the Indian had the right to use and occupy as much of the tribal land as he could beneficially employ." 293 Reintroducing these original indigenous systems of land tenure was already seen as difficult in 1934, with the new federal system having "taken deep root." ${ }^{294}$ Of course those challenges persist, and are magnified, today.

Nonetheless, some renewed recognition of the potential for reinstating informal owner's use rights on Indian lands, in light of the expansive needs for housing, income, and development among Indian people, and the large chunks of unused land theoretically owned by these individuals, has exciting potential. Owner's use alone may not solve every land tenure problem. The combined factors of fractionation and the federal trust restrictions do limit the overall utility of land for individual owners, and issues like access to credit for development on these lands will remain. ${ }^{295}$ Indian landowners may also be limited by the relatively small size of some original allotments, general remoteness of some of these lands, or actual disagreements among co-owners. ${ }^{296}$ Nonetheless, while the current federal trust status provides many protections against further land loss and also helps serve as a protective barrier between tribes, tribal citizens, and states seeking to assert greater

292. See, e.g., Leeds, Burning, supra note 10, at 496; see also supra notes 84-86 and accompanying text.

293. 1935 LAND PLANNING, supra note 110 , at 4.

294. Id. at $4,20$.

295. Gilbert \& Taylor, supra note 167, at 115, 124 (describing Pima Agency's position that within a working unit of consolidated allotment tracts "authority should be extended to the owners of said land to utilize the unit land base and/or otherwise dispose of some in part or all to owners in the unit or otherwise"); see Williams, supra note 167, at 712-13 (describing credit access issues).

296. The small size of allotments was another issue; in many instances, many tracts of allotted land had to be combined to form an economical working unit. See Gilbert \& Taylor, supra note 167, at 123 . 
jurisdiction within Indian Country, ${ }^{297}$ an ideal co-ownership system would maintain the benefits of this trust status for Indian landowners while also maximizing flexibility for Indian use and determination of Indian lands for Indian futures.

Reforms could maximize the advantages of the trust status, including the federal record-keeping and administrative role that is essential and fair in light of the federal cause of the current fractionation challenges, while also enabling some more flexible owner's use arrangements and streamlining the paternalistic components of the federal trust status. For example, I have previously argued that the federal government must continue to act at least as an administrative trustee for these co-ownersbearing the cost of maintaining these complex records, for example-and that the current fractionation problems cannot be resolved just by a simple removal of the federal trustee relationship. ${ }^{298}$ However, carefully crafted trust reforms could help, including for example eliminating just the Secretary's approval requirements for transactions among tribal citizens where tribal laws could protect individuals from fraud or unfair dealings without cumbersome federal oversight of every transaction. ${ }^{299}$ That possibility holds great promise; especially as the Cobell buy-back plan takes effect, and the average number of co-owners on individual tracts decreases, and the size of individual shares potentially increase.

In addition, the Department of Interior could make relatively modest changes to its leasing programs to start to better balance the interests of both local and distant absentee owners and avoid the perverse incentives of the current system, at least while simultaneously supporting tribes in implementing their own local tenure reforms. For example, while current laws theoretically seek to promote democratic decision-making among co-owners of an allotment by reducing the number of interests that must consent to a lease, the Department of Interior could revise the definition of "majority" for these purposes so that the agreement of a majority of the landowners who responded to the BIA's inquiry regarding any given land transaction would bind the other nonparticipating landowners. This would create some gentle pressure on otherwise remote or absent landowners to participate, and if they fail to do so, they should be bound by the decision of the participating co-

297. Many individual Indians may also be reluctant for outright termination of the trust status because they see it as tied to benefits such as tax exemptions and their "eligibility to the various land management and other services rendered by the Bureau of Indian Affairs without charge or at relatively low fees." Id. at 116 .

298. See Shoemaker, supra note 6, at 762-63, 777.

299. Id. at $781-82$. 
owners, at least under a waiver or laches theory. In addition, Indian landowners should be permitted to match lease offers from third parties seeking to use their land in all cases, and tribal credit institutions for Indian landowners seeking to invest in use of their own land must be further developed. Finally, even if the Department of Interior's primary concern is financial return for absentee landowners, the Department must evaluate how its current owner's use policy is counter-productive-at least for the approximately one-half of jointly-owned lands that are presently sitting idle or not generating any income at all.

\section{B. Property Rights Matter}

Certainly, simply resolving to embrace a more flexible owner's use priority in the Indian land tenure system would quickly invite some difficult value-setting questions. Are only particular types of uses permitted by owners on the land? Are there eligibility requirements for an "owner" to qualify to take direct possession of the land? What if an outsider (perhaps an Indian citizen of another tribe) simply purchased a small interest of land from a distant heir and then sought to use the entire allotment at a discounted rate? What if a tribal member did that? Could she really claim a trumping owner's use right as against other heirs and owners? What if multiple co-owners disagree about how to share in use of the land? What if a lease has already been executed? Can the objecting co-owner use the land in cooperation with the lessee, or is she prohibited from making her own uses of the land until there is an opening or an actual vacancy on the land? Should a co-owner in possession have to pay rent for her possession? How will that rent amount be determined? Who pays for improvements?

How all of these questions are answered will inform which values the property rules promote and prioritize. ${ }^{300}$ One of the certain lessons of allotment and the current Indian land tenure problem is that uniform, topdown federal property reforms do not work in Indian Country and have expansive unintended consequences. In addition, as evidenced by the lasting and widespread effects of allotment itself, property rules are significant and do matter on several social, political, cultural, and economic levels. Although both the federal government, and by extension the American taxpayer, have a stake in how this co-ownership form is defined to the extent it might result in federal liability or creates a

300. Cf. Dagan \& Heller, supra note 11, at 572-73 (outlining authors' view of the values a "liberal commons" model of co-ownership should promote). 
federal expense in the continued administration of excessively fractionated land, it is the Indian people and Indian nations who must be allowed to assert ultimate control over their own tenure choices. Consistent with the current federal policy to encourage Indian selfdetermination in many spheres, there must be some tribal flexibility in the administration of a property system, and nearly every scholar or student to address any aspect of this issue agrees that solutions must be tribally chosen consistent with local objectives. ${ }^{301}$

The difficulty for tribes in creating, implementing, and securely establishing these new tenure systems must not be under-estimated. The federal government should act to clarify tribes' pre-existing sovereign authority to make these changes, in order to avoid dispute and encourage certainty in the process. ${ }^{302}$ However, tribes must also take a significant political risk. There is no way to reform these tenure systems without displeasing someone. While there will be no solution that satisfies all co-owners, the fact that the Cobell settlement has provided significant consolidation funds to purchase small, undivided interests from willing sellers may make this change in property system more palatable right now. To the extent a remote owner feels prejudiced by the ability of a possessing owner to use the land, perhaps at lower than market rates, that owner could have a viable exit option at this unique moment in time by selling his or her interest to the tribe under the Cobell buy-back program. ${ }^{303}$

301. See, e.g., Bobroff, supra note 77, at 1622-23; Davidson, supra note 9, at 605-12, 617; Guzman, supra note 96, at 658-61; Hoelle, supra note 77, at 594; Leeds, Burning, supra note 10, at 496-97; Leeds, Moving, supra note 10, at 455-61; Monette, supra note 10, at 62-63; Sawers, supra note 9 , at 426-31; Shoemaker, supra note 6 , at 730, 749. In addition, current federal policy seeks "to create the conditions for a new era in which the Indian future is determined by Indian acts and Indian decisions." Special Message to the Congress on Indian Affairs, 1 PUB. PAPERS 213 (July 8, 1970), available at $\mathrm{http} / /$ www.epa. gov/tribalportal/pdf/president-nixon70.pdf.

302. One should also not underestimate the difficulty in getting a federal agency like the BIA to abdicate its previously asserted authority over these issues. See, e.g., Felix S. Cohen, The Erosion of Indian Rights, 1950-1953: A Case Study in Bureaucracy, 62 YALE L.J. 348, 387-89 (1953) (describing "the problem of bureaucratic aggrandizement" in Indian law); see also Monette, supra note 10, at 58-59 (describing the Department of Interior's objection to earlier version of AIARMA that would have expressly recognized obligation to abide by tribal laws, including with respect to use of allotments); Cadotte v. Acting Aberdeen Area Dir., Bureau of Indian Affairs, 31 I.B.I.A. 175, 176 (1997) (suggesting in dicta that tribes may already retain the right to make some modifications to authorized owner's use rights on allotments).

303. See supra note 17 and accompanying text. 


\section{Trust Conflicts Must Be Further Resolved}

Finally, while it is true that any future property decisions must be designed by tribes as reflections of their own local priorities, values, and resource conditions, the federal government must also respond and strongly support this endeavor. This is true for many reasons. The current system may expose the federal government to legal liability and, simultaneously, is having the perverse effect of actually exacerbating the fractionation it is supposed to be ameliorating. In addition, the federal government has previously acknowledged that the fractionation issues that are flaming these challenges were created by federal law in the first place, and the federal government therefore has the obligation to support solutions and bear the burden of its mistakes as the solution is sought.

As for potential federal liability for continued inaction, the elimination of the "right to use" and "right to possession" sticks in the Indian landowners' property bundle may result in takings liability under the Fifth Amendment. It may be a violation of the federal trust responsibility to Indian landowners to burden use and possession so substantially, or it may constitute an ultra vires agency action in violation of the repeated federal laws intended, conversely, to promote Indian use of Indian land. All of these potential liabilities warrant their own, more detailed analysis beyond the scope of this article. ${ }^{304}$ However, the legitimacy of the Department of Interior's current and future actions must be seriously evaluated.

More fundamentally, however, the trend to eliminate owner's use and possession rights reflects a larger identity crisis within the Department of Interior and within federal Indian law. The trust-based restrictions on these lands are growing rather than receding over time, and the foundations for this must be explored. Is the Department of Interior really a trustee for absentee landowners" "right to income," or for the "right to possession" of local landowners who would make direct use of the land? Or should the Department of Interior primarily support tribal governments in their own application of reemerging tribal property laws? These questions are not easy ones to answer as many Indian landowners have a reasonable and well-founded expectation that, after the federal government caused fractionation, it must do its best by the remaining owners of these tiny fractional interests. ${ }^{305}$ Because of the

304. The author intends to address these issues further in future work.

305. See, e.g., 2006 LEASING HANDBOOK, supra note 208, at 2 (stating the Department of Interior identifies leasing as one of the major ways it fulfills its trust responsibility). 
extreme degree of fractionation, BIA leasing of the property for its highest rental value on behalf of the hundreds or thousands of co-owners may be the best and most fair result in many instances. However, the Department of Interior's decision-making seems increasingly to overlook the tension between the financial interests of absentee landowners and the property rights of landowners themselves. An exclusive emphasis on the financial return for absentee landownership, at the expense of landowners' own possession rights, is contrary to at least one primary purpose of the individual lands' trust status: to protect, promote, and enable Indian landowners, as citizens of functioning sovereign tribal governments, to make direct use of their own lands while preventing further land loss. ${ }^{306}$

\section{CONCLUSION}

Every other proposed Indian land tenure reform to date has failed to create tribal economies of enfranchised landowners making direct use of their own land. The modern structural design of individual Indian's property rights within co-ownership forms is now contributing to this problem. Current rules perversely prohibit Indian possession even if that land is currently not in use at all, and instead the rules incentivize landowner inaction by eliminating any costs of continued ownership and making it more profitable, because of the nature of BIA oversight, for landowners to do nothing rather than try to coordinate actively with other co-owners.

Although the original allotment proponents intended to create a pattern of self-supporting farming entrepreneurship throughout Indian Country by implementing a version of private property on top of existing indigenous land use arrangements, this effort failed. Today, Indians endure one of the most complicated land tenure systems ever designed, and the smoke and mirrors created by the complex bureaucratic system has, to date, obscured the fact that, more recently, Indian property systems have evolved into an unusual and highly unique form of "property" without any meaningful possession rights for many individual

306. See also Reid Peyton Chambers, Compatibility of the Federal Trust Responsibility with Self-Determination of Indian Tribes: Reflections on Development of the Federal Trust Responsibility in the Twenty-First Century, Rocky MTN. MIN. L. Found. 7-9 (2005), available at http://www.doi.gov/cobell/commission/upload/5-2-Rocky-Mountain-Mineral-Law-Foundation-9-2705-Compatibility-of-the-Federal-Trust-Responsibility.PDF (framing federal trust responsibility as centrally aimed at protecting the status of tribes as distinct and self-governing political units); see generally Monette, supra note 10. 
landowners. Tribes must be supported in developing more flexible and coherent tenure systems for Indians' use of Indian lands. The Department of Interior must also evaluate the institutional disincentives it is creating by the current system and work to favor active owner participation in land management. In many cases, this may call for prioritizing possession and use by individual Indian landowners. Although a continuation of federal support through administrative, accounting, and record-keeping functions is essential to maintain this complicated system, tribally driven property reforms are an important next step. 